\title{
Multifunctionality of Agriculture: A Review of Definitions, Evidence and Instruments
}

\author{
Guido Van Huylenbroeck \\ Ghent University, Department of Agricultural Economics \\ Coupure Links 653, 9000 Ghent, Belgium \\ email: Guido.VanHuylenbroeck@UGent.be \\ http://www . agecon. ugent.be/vanhuylenbroeck_e.html \\ Valerie Vandermeulen \\ same address \\ email: Valerie.Vandermeulen@UGent.be \\ Evy Mettepenningen \\ same address \\ email: Evy.Mettepenningen@UGent.be \\ Ann Verspecht \\ same address \\ email: Ann.Verspecht@UGent.be

\section{Living Reviews in Landscape Research ISSN 1863-7329}

Accepted on 17 April 2007

Published on 25 June 2007

\begin{abstract}
In this contribution we try to look at the new role for agriculture in rural areas by reviewing the concept of multifunctional agriculture as well as the analytical frameworks used. Next, we review the existing evidence about the multifunctional role of farming. Although not overwhelming, the existing literature shows that agriculture contributes to the rural wealth not only through the production of commodities, but also by the delivery of non-tradable goods. This contribution can be both direct through increased values for properties or economic benefits in the tourism sector, but also indirect through conservation of rural heritage or agriecological systems. Next we focus on how this role of agriculture can be stimulated. It is argued that multifunctionality can be a unifying principle to bring the productive and non-productive functions into harmony. This requires the development of new institutional arrangements and a major change in policy incentives.
\end{abstract}

Keywords: Multifunctional agriculture, institutional arrangements, agricultural policy

This review is licensed under a Creative Commons Attribution-Non-Commercial-NoDerivs 2.0 Germany License. http://creativecommons.org/licenses/by-nc-nd/2.0/de/ 


\section{Imprint / Terms of Use}

Living Reviews in Landscape Research is a peer reviewed open access journal published by the Leibniz Centre for Agricultural Landscape Research (ZALF), Eberswalder Straße 84, 15374 Müncheberg, Germany. ISSN 1863-7329.

This review is licensed under a Creative Commons Attribution-Non-Commercial-NoDerivs 2.0 Germany License: http://creativecommons.org/licenses/by-nc-nd/2.0/de/

Because a Living Reviews article can evolve over time, we recommend to cite the article as follows:

Guido Van Huylenbroeck, Valerie Vandermeulen, Evy Mettepenningen and Ann Verspecht,

"Multifunctionality of Agriculture: A Review of Definitions, Evidence and Instruments", Living Rev. Landscape Res., 1, (2007), 3. [Online Article]: cited [<date $>$ ], http://www.livingreviews.org/lrlr-2007-3

The date given as $<$ date $>$ then uniquely identifies the version of the article you are referring to.

\section{Article Revisions}

Living Reviews supports two different ways to keep its articles up-to-date:

Fast-track revision A fast-track revision provides the author with the opportunity to add short notices of current research results, trends and developments, or important publications to the article. A fast-track revision is refereed by the responsible subject editor. If an article has undergone a fast-track revision, a summary of changes will be listed here.

Major update A major update will include substantial changes and additions and is subject to full external refereeing. It is published with a new publication number.

For detailed documentation of an article's evolution, please refer always to the history document of the article's online version at http://www.livingreviews.org/lrlr-2007-3. 


\section{Contents}

1 Introduction $\quad 5$

2 Viewpoints and definitions $\quad 7$

2.1 Supply vision . . . . . . . . . . . . . . . . . . . . . 8

2.2 Demand vision . . . . . . . . . . . . . . . . . . . 10

3 Analytical frameworks $\quad 12$

4 Evidence about the multifunctionality of agriculture $\quad 16$

4.1 Economic function . . . . . . . . . . . . . . . . . . . . . . . . . 17

4.2 Social function . . . . . . . . . . . . . . . . . . . . . 18

4.3 Environmental function . . . . . . . . . . . . . . . . . . 20

5 Multifunctionality as a policy paradigm $\quad \mathbf{2 2}$

5.1 Shifting policy paradigm . . . . . . . . . . . . . . . . . 22

5.2 Policies and instruments in the multifunctionality paradigm . . . . . . . . 25

$\begin{array}{llr}6 & \text { Conclusions } & 29\end{array}$

$\begin{array}{ll}\text { A Appendix } & 31\end{array}$

$\begin{array}{ll}\text { References } & 33\end{array}$

\section{List of Tables}

1 Competing paradigms in agricultural policy . . . . . . . . . . . . . . . . 23

2 Multifunctional development models . . . . . . . . . . . . . . . . . 27

3 Examples of non-commodity outputs of agriculture and their characteristics . . . . 31 



\section{Introduction}

Throughout history agriculture has played a dominant role in the development of rural areas and in the shaping of rural landscapes. However, the role of agriculture for the future of rural areas is presently under discussion. Although agriculture remains still today for many rural areas an important economic activity and important factor for the creation of wealth and employment (both directly and indirectly), its dominant role in the rural economy is declining. At the same time, however, there are signs that society formulates some new expectations on the role of agriculture. Besides an economic contribution from food production, society increasingly expects agriculture to contribute to environmental and landscape services, water management and flood control, social care and cohesion and so on. The reason is, on the one hand, that agriculture continues to be the far most largest user of land (more than $50 \%$ of total EU area) and that rural areas are increasingly shifting from a productive area to what can be called a consumptive area (Potter and Tilzey, 2005) that needs to deliver social, recreational or maintenance functions.

Rural areas are also subject of a rapid urbanisation process, especially in many European regions, like the fringe of Brussels (Figure 1). Modern traffic and communication technologies have exported the urban way of life to the countryside putting pressure on rural traditions and way of life. It makes that the traditional harmony and responsiveness between agriculture and society has been broken and requires reinstatement (Delgado et al., 2003).

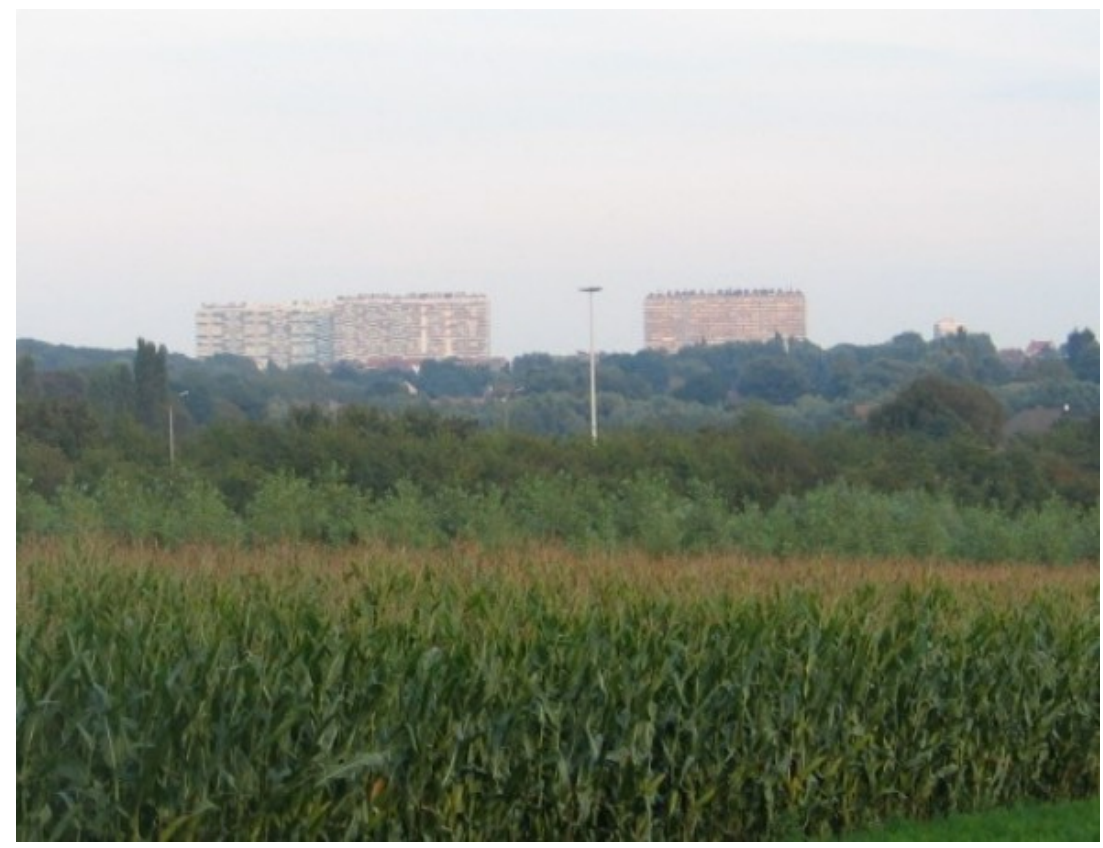

Figure 1: Landscape in the fringe of Brussels with an agricultural character.

Multifunctionality is therefore argued to be the new unifying paradigm to bring post-modern agriculture in accordance with the new societal demands. It is emphasizing that in addition to producing food and fibre, agriculture also produces a wide range of non-commodity goods and services, shapes the environment, affects social and cultural systems and contributes to economic growth. The background on the debate on multifunctionality as a process of agricultural policy reform, started in the mid 1980s. At that time agricultural support and protection were at historically high levels and there was considerable tension in international agricultural trade (Cahill, 
2001). The term "multifunctional agriculture" emerged on the international stage as early as 1992 , at the Rio Earth Summit. The emergence of the concept of multifunctionality responds to a wide range of concerns about significant, worldwide changes in agriculture and rural areas. The main aim of the notion of multifunctionality is to bring the above issues into a consistent framework.

The OECD Declaration of the Agricultural Ministers Committee (Maier and Shobayashi, 2001) defines multifunctionality of agriculture as follows:

"Beyond its primary function of producing food and fibre, agricultural activity can also shape the landscape, provide environmental benefits such as land conservation, the sustainable management of renewable natural resources and the preservation of biodiversity, and contribute to the socio-economic viability of many rural areas. Agriculture is multifunctional when it has one or several functions in addition to its primary role of producing food and fibre."

Although the concept is rather simple, its translation into policies remains however controversial (Dobbs and Pretty, 2004).

In this article we first try, based on literature review and own research, to give an overview of viewpoints and definitions of multifunctionality of agriculture as found in mainly economic and social sciences research. Next we review some analytical frameworks that can be used to study or analyse multifunctionality. This will be followed by a summary of existing evidence on the multifunctional role of agriculture. This overview article ends with some own thoughts on multifunctionality as a policy paradigm and on institutional arrangements and instruments that could be potentially used to push multifunctional agriculture further. In the conclusion we emphasize the need for further empirical research. Because of our own background, we focus in this overview mainly on the socio-economic studies on multifunctionality. We acknowledge that this may give a biased view as there exist also other schools on multifunctionality which focus more on multifunctionality as related to ecosystem services and landscape planning (see e.g. Helming and Wiggering, 2003). We consider therefore the main contribution of this article as complementing this literature which maybe more familiar to landscape researchers with a social sciences viewpoint. 


\section{Viewpoints and definitions}

When speaking about multifunctionality we need first to define the concept. The socio-economic literature on multifunctionality provides several definitions for this concept, and uses different terms to describe the same phenomenon. Since this multitude of definitions hampers the research on the topic, impeding for example the search for appropriate literature, we give an overview of the existing definitions and finally express an own viewpoint.

In the broadest sense, multifunctionality of agriculture includes four kinds of functions provided by agricultural enterprises. The green functions consist, amongst others, of landscape management and the upkeep of landscape amenities, wildlife management, the creation of wildlife habitat and animal welfare, the maintenance of biodiversity, improvement of nutrient recycling and limitation of carbon sinks. Other public benefits that can be created by agriculture are the blue services and contain water management, improvement of water quality, flood control, water harvesting and creation of (wind-) energy. A third kind are called yellow services and refer to the role of farming for rural cohesion and vitality, ambience and development, exploiting cultural and historical heritages, creating a regional identity and offering hunting, agro-tourism and agro-entertainment. Finally, many authors acknowledge the white functions produced by agriculture, such as food security and safety (Aldington, 1998; Dobbs and Pretty, 2001; Harwood, 2003; Moyer and Josling, 2002; Jongeneel and Slangen, 2004).

Including all these aspects makes it difficult to build a workable definition even more because many authors give a different interpretation to multifunctional agriculture. Following Hediger (2004), the concept accounts for the fact that agriculture is an economic activity that, beyond its primary function of supplying food and fibre, provides various non-market outputs to society. A key reference with respect to the analytical concepts is (Maier and Shobayashi, 2001) who made a study on behalf of OECD. They state that these non-market outputs constitute potential sources of market failure and create theoretical arguments for public intervention because they are often joint products, externalities or public goods. 'Jointness' of production means that the production of one good or service is interrelated with another. 'Externalities' means that the one who produces the outputs is not remunerated for it (in case of positive externalities) or does not pay for it (in case of negative externalities). 'Public goods' refers to the fact that there is no or low excludability (meaning that the property holder (if any) can not exclude other people from the benefits) and no or insufficient rivalry (meaning that the good is not destroyed when others use it and is thus available for more than one beneficiary). For an extensive definition of these concepts in relation to multifunctionality see, inter alias, Maier and Shobayashi (2001) or Fahlbeck $(2004 \mathrm{a}, \mathrm{b})$ and for a more formal derivation of their properties we refer inter alias to Vanslembrouck and Van Huylenbroeck (2005).

In general, two main schools or approaches on multifunctionality of agriculture can be distinguished (Aumand et al., 2006): the first one is focusing on the supply side issue (positive approach), while the second is focusing on the demand side issue (normative approach) (Maier and Shobayashi, 2001). Besides these two analytical approaches, there is also a third more holistic interpretation of the concept of multifunctionality, rooted mainly in rural sociology and rural geography, referring to multifunctionality as a new kind of locally embedded model of agriculture. Multifunctionality is in this third view a way to describe a different farming system that is more territorially embedded, making use of local resources and trying to build a new link between consumers and producers (Wilson, 2001; Renting et al., 2003; van der Ploeg and Roep, 2003). In a sense, this view links both the supply and demand side by relating it to the rural space and the whole agro-food system in which agricultural activities take place. Wilson (2004) speaks in this context of multifunctionality as a regime as it reflects a further transition after the shift from productivism to post-productivism in agriculture.

Although we agree that multifunctionality can be a unifying principle to construct a new agri- 
food model, we deliberately focus in this section on the first two approaches because analytically the term multifunctionality should not be mixed with other related but clearly different terms such as diversification and pluri-activity. As analytical concept, multifunctionality refers to the fact that one activity can have different outputs. It is thus related to an economic activity (either a single activity like the cultivation of wheat or a group of activities like food production), while diversification means that different economic activities (e.g. food production and tourism) are combined within the same management unit (in casu the farm or the agricultural sector). Pluri-activity refers to the fact that one person or a group of persons (farmers or rural entrepreneurs) are involved in different activities (e.g. farming and non-farming). On the one end we can thus have a specialised farm with workers only involved in food production, but being multifunctional because the food production activity results in different benefits for society, and at the other end a diversified enterprise with persons involved in different activities and thus pluri-active, but where every activity in itself could be theoretically mono-functional. Once we accept that multifunctionality of activities is a useful normative concept we can look what it means for agricultural policy or our agri-food production model (Section 5).

\subsection{Supply vision}

First we look at the supply side approach of multifunctionality. The supply side viewpoint defines multifunctionality mainly in terms of multiple joint outputs of an activity or of a combination of activities (Doornbos and Pastoor, 2001). Romstad et al. (2000) speak about linked outputs, that can be private or public, main or secondary and that can be intentionally produced or not (by-product) (Romstad et al., 2000; Vatn, 2000, 2002; Romstad, 2004).

This definition of multifunctionality restores the traditional economists' concern about joint products in agriculture (Freshwater and Jia, 2004). Where, initially, the jointness concept referred purely to a technical link between two outputs in fixed proportions, with multifunctionality it becomes a more general concept with the possibility of variable proportions. Multifunctionality is thus understood as the production of more than one output through the use of inputs (Figure 2). These outputs may be complementary (this means if there is more production of one output, there is also more of the other), or competing (being substitutes) (see also Havlik et al., 2005).

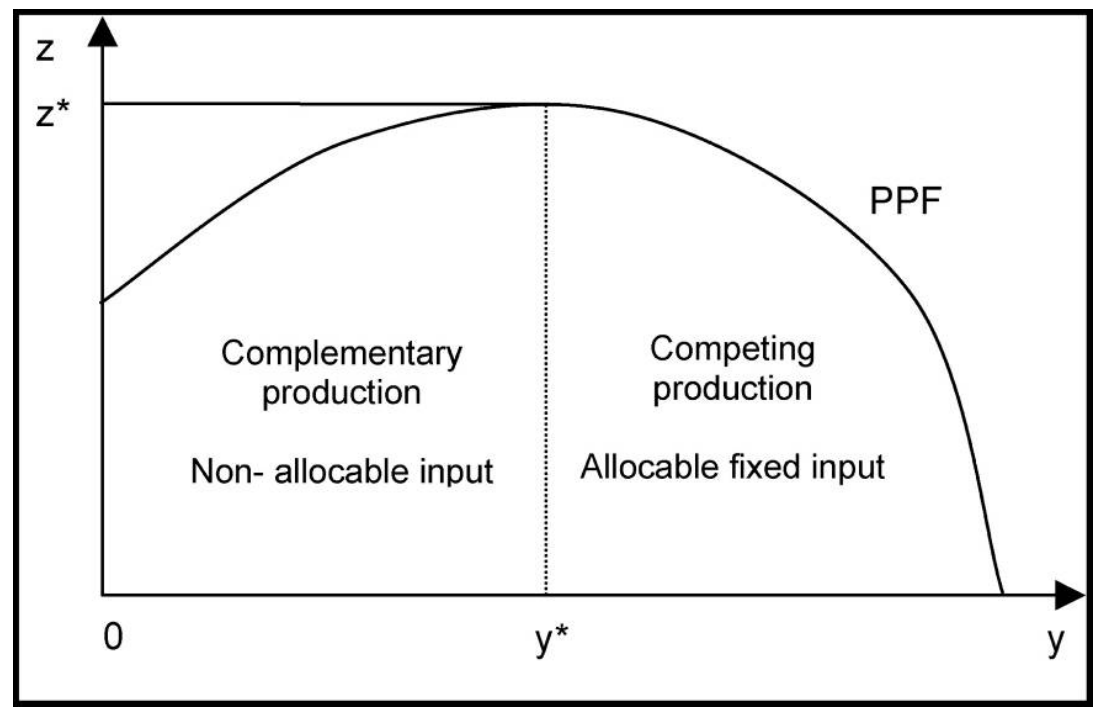

Figure 2: Relationship between joint outputs (Havlik et al., 2005). 
According to OECD (Maier and Shobayashi, 2001) three reasons for jointness are frequently distinguished.

- Technical interdependencies in the production process occur in situations where increases or decreases in the level of one output influence the supply of other outputs, without any change in input allocation to these outputs. A consequence is that the marginal productivities of the input used in the production of one output depend on how much is produced of the others. Two outputs are technically complementary if an increase in the supply of one raises the marginal input productivities in producing the other. They are technically competing if the reverse holds (Doll and Orazem, 1978). Therefore technical interdependencies are at the origin of many of the negative non-commodity outputs of agriculture, including soil erosion, chemical residuals, nutrient leaching, etc. Positive effects due to technical interdependencies include, for instance, the impacts of crop rotation on nutrient balances and soil productivity.

- Non-allocable inputs can create jointness in production, where multiple outputs are obtained from the same input (Casavant et al., 1999). A classical example is the production of mutton and wool, which are jointly obtained from raising sheep. The production of meat and manure, or the association of landscape with particular production systems are other examples of joint products caused by non-allocable inputs. Very often specific farming systems create a certain landscape as non-commodity output through their commodity production. However, while these outputs are joint, they are rarely produced in fixed proportions and using different production methods can modify those proportions.

- Allocable inputs are fixed at farm level, but can be allocated to various outputs in the production process. An increase or decrease in the production of one output changes the amount of the fixed factor available for the supply of others. For farmers this is especially important according to land and self-employed labour. In the short run these production factors are allocable fixed factors.

It is clear that this distinction in categories does not always correspond to the situation in reality. The overall jointness effect is often due to a combination of different sources, the relative importance of which can be difficult to assess. For more formal representations of jointness see among others Vatn (2002) and Havlik et al. (2005).

Buysse et al. (2007) indicate that jointness is a mere technical concept but that the real choice question is related to whether the production of the non-commodities is free or only weakly disposable. In case of free (or strong) disposability, joint production is no problem as it means that the by-products can be disposed without costs or in other words negative effects can be absorbed by the environment or positive effects can be produced without additional costs or reduction of profits. However, joint products can often not be freely disposed (also called weak disposability) or have in other words a price. In the case of undesirable outputs, weak disposability means that the reduction of the by-product can only be achieved by simultaneously reducing some desirable outputs and/or resource-using abatement (Färe et al., 1993). In the case of positive functions it means that extra costs have to be made to produce the joint product or that it affects the profitability of the main output. Varian (2002) links the property of free disposal to monotonicity. Weak disposability, on the other hand, is linked to congestion and has to be placed in the context of early environmental theoretical insights (Ayres and Kneese, 1969). This link to congestion implicitly refers to the notion of ambivalent joint production, which is the possibility that an output may have a positive value in one circumstance and a negative value in another (Freshwater and Jia, 2004). Joint production is analytically also linked to the concept of non-separability (Wossink et al., 2001) that states that abatement of negative externalities or provision of positive externalities can be achieved by changing the production technology or system. As we shall see in Section 3, multifunctionality depends indeed on the activity level. The same activity (e.g. wheat production) will 
result in another output bundle when produced intensively or more extensively (like e.g. in organic production). In other words multifunctionality will be linked to farming practices, production technologies and farming systems.

\subsection{Demand vision}

In the supply vision, multifunctionality is merely a characteristic of the agricultural production process rather than a societal objective. This is opposite to the second view on multifunctionality which looks at the demand side with respect to the multiple functions agriculture can provide. This viewpoint is demand oriented and departures from the social expectations on agriculture. In this sense, Casini et al. (2004) define the functions of agriculture as: the factual or potential provision of material or immaterial goods and services that satisfy social expectations, meeting societal demand/needs through the structure of the agricultural sector, agricultural production processes and the spatial extent of agriculture.

This definition is more territorially embedded and is linked to the concept of rural areas as consumptive space. The multifunctionality of agriculture covers indeed a wide range of potential attributes which relate primarily to land use such as protection of wildlife habitat, biodiversity, landscape amenities (Figure 3), and to social attributes such as the viability of rural communities and food security (Blandford and Boisvert, 2004). The unit of analysis in this approach is therefore the land. de Groot et al. (2002) speak from an ecosystem point of view about regulation, habitat, production and information functions. To these functions they assign three categories of values. Ecological values are connected to the importance of an ecosystem that is determined by the integrity of regulation and habitat functions and by ecosystem parameters. Social values are related to education, cultural diversity and heritage, and are mainly linked with information functions. Economic values are benefits that somebody can have from either market goods (for which the market price corresponds with the economic value) or non-market goods (that can indirectly lead to economic benefits because they may give extra value to economic activities). In a wider concept they also encompass non-use values such as existence, bequest or option values (Randall, 2002). Bastian and Schreiber (1999) classify landscape functions hierarchically in about the same three function groups: (1) production functions (economic function) (2) regulation functions (ecological function) (3) social/human habitat functions (social function). Vatn (2002) explains that in the appreciation of functions both qualitative aspects and quantitative aspects play a role. Indeed not only the presence (quantity) of a good is important, but also the level of output (quality). The aesthetic value of a landscape may depend both on the level of biodiversity and the variety of the ecosystems present, as on the amount of the different ecosystems. Mollard (2003) further suggests a distinction between two types of externalities. The "direct" externalities rise from the existence of technical or economic jointure with the agricultural production. It is the case of biological diversity or water quality. On the other hand, there are the "indirect" externalities whose link with the agricultural production is less clear because it's not easy to ascribe their supply to a specific agent. This is the case for the cultural value of the landscapes, or the ecological functions of agro-ecosystems for which the participation of other actors than farmers may not be negligible.

In our view, a major difference between the positive and normative viewpoint lies in the implicit treatment of externalities. Where the supply definition considers negative and positive externalities as good and bad outputs respectively and treats them equal, the second definition privileges the positive contributions of agriculture and speaks rather of a potential reduction in the provision of functions when agricultural practices threaten the delivery of potential benefits. This view on the multifunctionality concept has therefore in our view the merit to emphasize the positive contributions or benefits (see also the definition of Hediger, 2004) that agriculture may have to society. In this sense the concept becomes normative as it can be used as something that needs to be maximized or achieved. The contributions are not exclusive (only negative or positive) but

Living Reviews in Landscape Research

http://www. livingreviews.org/lrlr-2007-3 
may be interlinked (complementary or substitutes) as illustrated with the example of fertilisation that may be positive for landscape quality but reduces biodiversity or water quality (Casini et al., 2004).

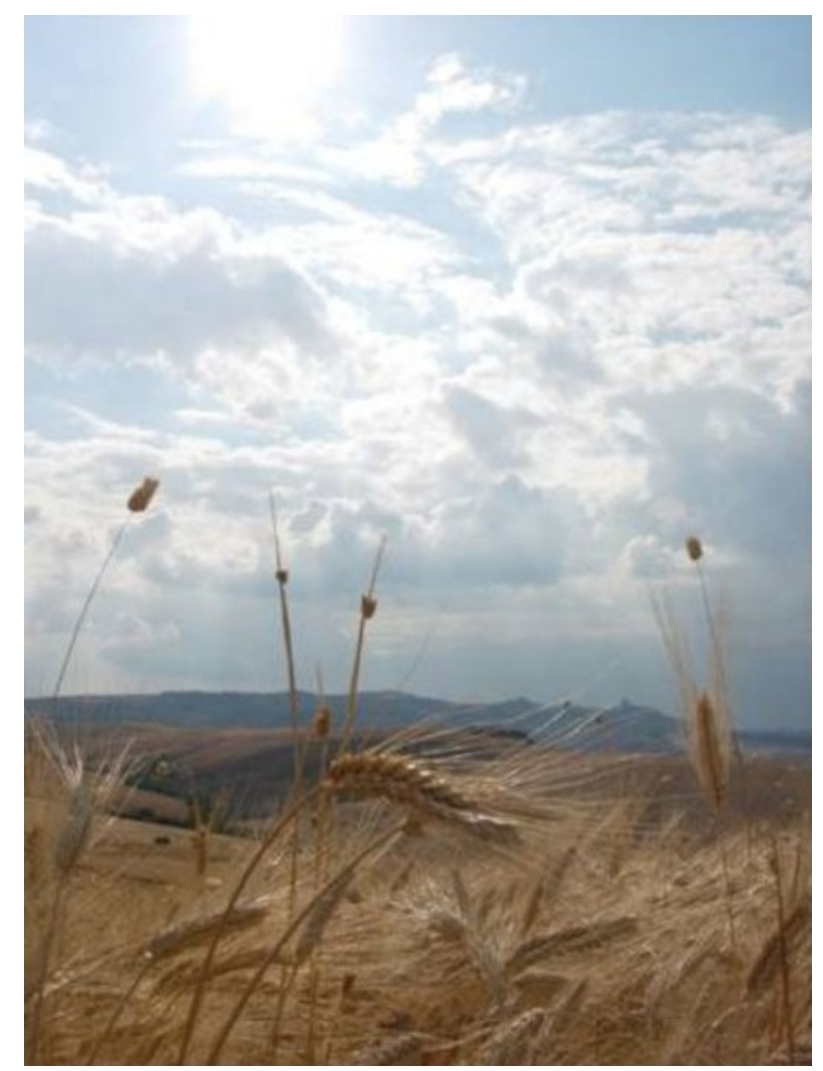

Figure 3: View on a Tuscan landscape with an agricultural character.

As indicated above, the concept of externality refers to market failure (Maier and Shobayashi, 2001) and in this sense the distinction between an increase in benefits or a reduction of benefits makes sense. For positive externalities (which affect in a positive way social welfare), the absence of a market involves a sub-optimal offer. As positive externalities are consumed by their beneficiaries without paying a price, farmers do not have incentives to take into account in their decision-making process the impact of their actions on the social welfare. It is a matter of incongruence between private and public interests. There is then a need for arrangements (public or private) to correct this failure of the market to coordinate the offer of positive externalities. By contrast, for negative externalities, an overproduction of another output is probable because the private producer is interested in maximising his private profit whereas a lower level of production would be necessary to respect the socially acceptable level of the non-commodity output. Here, public intervention can be necessary to avoid a skewed output bundle. 


\section{Analytical frameworks}

While the previous section focussed on the definitions of multifunctional agriculture and described the different ways to approach it, this section provides analytical frameworks to assess the multifunctional character of farm systems. Important emphasis will be laid on the link between commodity and non-commodity production.

Although the supply and demand side visions on multifunctionality, described in the previous section, place another emphasis on the concept, it is rather clear that the core elements of multifunctionality are: (i) the existence of multiple commodity and non-commodity outputs that are jointly produced by agriculture; and (ii) the fact that some of the non-commodity outputs exhibit the characteristics of externalities or public goods, with the result that markets for these goods do not exist or function poorly.

In order to connect both approaches two aspects become important:

- The coupling between commodity and non-commodity output in agriculture: in general, literature reveals that jointness between these outputs is weak as long as externalities are positive (and conversely). This result is supported by an empirical study referring to OECD countries (Abler, 2001).

- The spatial scale of non-commodity output production: the question of spatial scale is important (from farm to landscape level) because diversity in systems (often linked with higher multifunctionality) can be reached by making individual farm systems more diverse or by connection at the territorial level of on itself specialised farm systems.

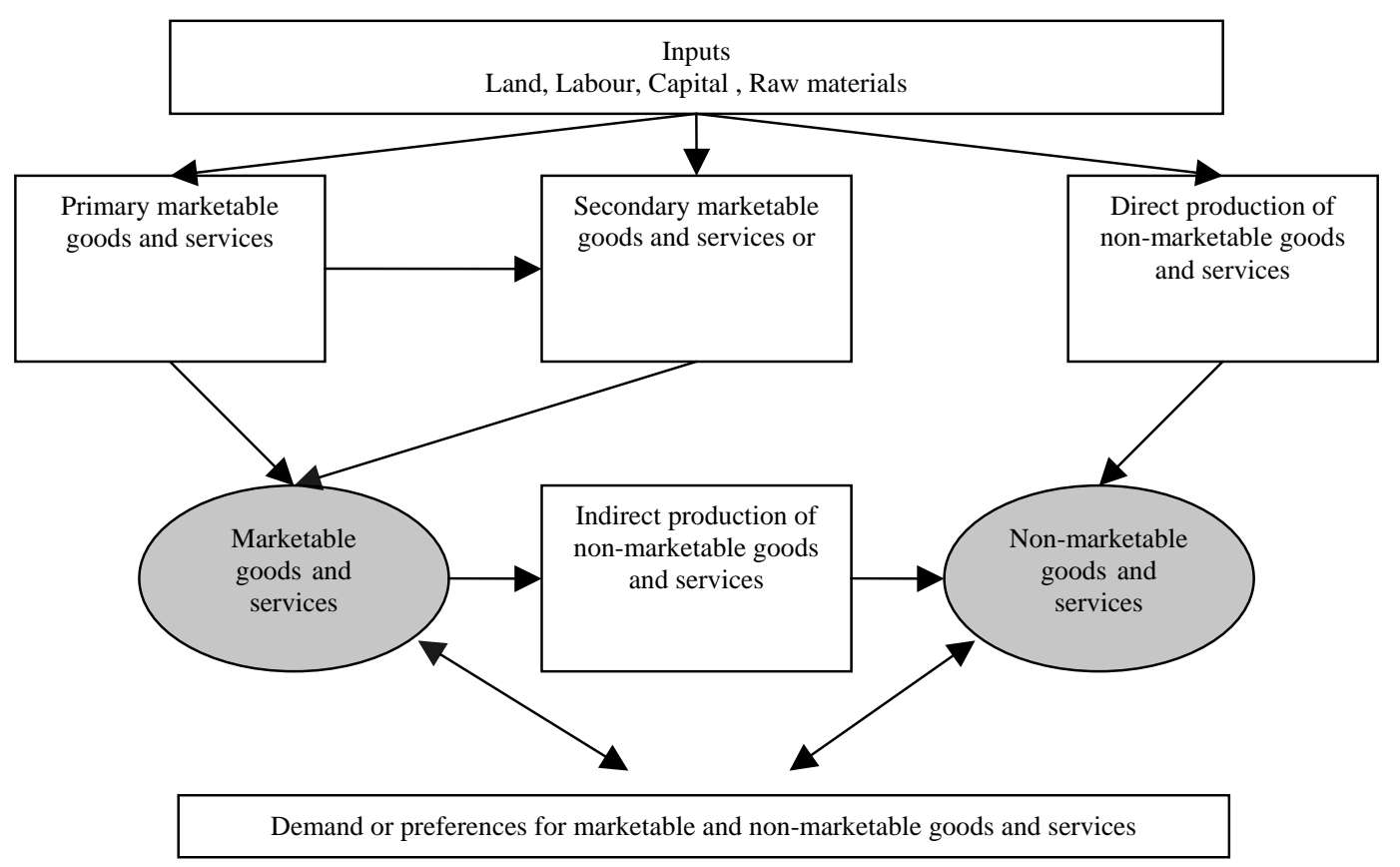

Figure 4: A farm system approach to the analysis of multifunctional agricultural production.

To study whether a farm, sector, or region is characterised by a multifunctional production system different analytical frameworks can be used. Figure 4 is an own attempt to bring together the supply and demand vision using a farm system approach. In this framework it is assumed 
that the farmer can use its primary inputs (land, labour, capital and raw materials) to produce primary commodities such as food and fibres (traditional products like milk, grains or wood or les traditional products such as bio-energy crops) or less traditional products or services (such as agro-tourism or wind energy). He can also combine (part of) these primary outputs with primary inputs to transform them into secondary marketable outputs such as yoghurt or cheese, or bioenergy (e.g. in case the farmer transforms energy crops or by-products of his primary production into energy). Both the primary and transformed goods and services mentioned are marketable and thus commodities. In addition a farmer can also produce (intentionally or not) directly nonmarketable goods and services such as landscape elements, biodiversity or other amenities (in case of fallow land e.g.) or indirectly affect non-commodity values or outputs through the production of both his primary or secondary marketable goods and services. By using the word services we incorporate activities such as farm tourism, landscape care, social care activities, but also nonintended services such as carbon sequestration, cultural services, consequences for environmental quality and so on.

Within a given market and policy setting, the economic activities of the farming system will result in a certain combination of the joint products, or in other words result in a specific configuration of the bundle of outputs. In order to connect this to the demand function we can then analyse whether this output bundle corresponds with societal demand or preferences. It is clear that in present Western societies the preferences for the output combination is different (e.g. a higher preference for environmental values) than e.g. 50 years ago when food supply and security were more important.

The above framework broadens the traditional view on farming and incorporates the vision on rural systems of e.g. van der Ploeg and Roep (2003) or Belletti et al. (2003), who advocate the broadening of traditional agricultural production through diversification, deepening and regrounding. The conceptual framework can further be used at farm, sector or regional level. At farm level we may look at multifunctionality by analysing the outputs of the economic activities of that farm (either specialised or diversified), while at sector level we can analyze the output bundle of the whole farming sector. At regional level, we will be interested in the output bundle of the territorial system composed of specialized and non-specialized farms and other enterprises.

To know whether the studied system is multifunctional it becomes important to study the technical linkages between non-commodity and commodity outputs (complementarity and substitutions between them), and to define the relationships between the production factors within the agricultural production process which give rise to such linkages (Ferrari, 2004). Maier and Shobayashi (2001), Cahill (2001) and Vanslembrouck and Van Huylenbroeck (2005) provide some guidelines to analytically investigate the linkages. They suggest looking at the following issues:

- the extent to which the non-commodity outputs of agriculture are linked to or can be dissociated from commodity production;

- whether there are economies of scope in the joint provision of commodity and non-commodity outputs;

- whether and how the production linkages are influenced by site-and area-specific conditions (spatial dimension);

- the possibilities of alternative provisions of the non-commodity outputs. Even if there is jointness with agricultural production, other providers can exist.

- finally the mutual influence among the non-commodity outputs or with other words the dependencies within the bundle of outputs.

Based on the above framework, Van Huylenbroeck and Vanslembrouck (2001) give some concrete examples (see Appendix A) of joint non-commodity outputs in agriculture: employment, 
food security, landscape, biodiversity, environmental quality (soil, air, water), cultural heritage (see Table 3 in the Appendix A).

These examples reveal the following: first of all, the link with the production level is only clear in case of negative externalities. In most other cases the coupling with the production level is weaker (see also Abler, 2001). This has to be interpreted as follows: agriculture or any form of cultivation is in most cases a necessary condition to obtain the non-commodity output, but the yield on itself is not as important. In a few cases however, above a certain level of production the non-commodity output decreases or is endangered (e.g. meadow birds are endangered if the farmer wants a first cutting of his grassland earlier than the breeding season, genetic diversity is not compatible with having only high yielding varieties).

Secondly, in all cases studied, the non-commodity output is dependent on the applied farm practices, systems or technologies. This confirms the production potential model of joint production stating that it will depend on economic conditions at what point of output combination farmers will produce. In most cases the non-commodity output is also linked to agricultural structures: specialisation and increased scale of farming have caused larger physical structures that allow the use of more modern technologies, resulting in less multifunctionality. All these factors together may contribute to the underprovision of certain functions. A specific problem is that the level of jointness is in most cases depending on topography, soil quality, climate conditions and so on and thus spatially differentiated, causing problems of competitiveness in case measures are taken in a particular region.

A third aspect is in how far non-agricultural provision of the non-commodity output is possible or in other words in how far delivery of non-commodity outputs can be de-coupled from commodity production. In theory it is sufficient to conserve the cultivation practices from which the non-commodity output depends on even if the commodities are not sold, meaning that the non-commodity output does not depend on the sales level. In practice however it will in most cases be a very expensive option to decouple the non-commodity production from commercial farming. Conservation of old practices will therefore only be considered either in the case of a high cultural heritage or other social value (e.g. conservation of high fruit trees) or in the case of a high ecological value (e.g. farming practices in an agro-ecological landscape conservation area). For non-commodity outputs with a high dependence on farming and for which the requirement is to reduce the intensity of farming, commercial farming will often be the most economic solution and instruments need to be found to give incentives to farmers to indeed reduce the farming intensity.

Fourthly, Van Huylenbroeck and Vanslembrouck (2001) focus on the interdependencies among non-commodity outputs. In general, they found a conflict between social functions (employment and rural viability) and environmental functions of agriculture. The reason is that (partial) decoupling will in general be linked to a reduction of the employment (directly or indirectly because of weakening of the competitiveness), at least if no instruments are found to remunerate the higher costs for the lower production of commodity outputs. In some cases there may be competition among some functions such as e.g. meadow bird conservation and bio-diversity in the meadows as both non-commodity outputs require different farming practices.

Finally, the authors analyse to what degree reductions of commodity prices are creating market failure in the provision of non-commodity outputs. A positive relation exists when as a result of price reductions, more extensive beef production systems are developed, which are good for meadow birds or for field flora. This is however only true as long as farmers do not switch to other commodities (e.g. ploughing their land). In other cases the effect is negative because price reductions stimulate farmers to cut further on costs and to apply more efficient farming systems which are less compatible with the delivery of the non-commodity output.

The examples (confirmed by the analysis of Abler, 2004, based on a larger set of examples) show that the analysis of the coupling between the non-commodity and the commodity outputs has to be done carefully to detect the nature of the jointness in production. An important point (see also

Living Reviews in Landscape Research

http://www. livingreviews.org/lrlr-2007-3 
Cahill, 2001) is that even if separation of commodity and non-commodity outputs is technically feasible, there may be potential for economies of scale. This means that joint production of several outputs will be cheaper than the separate production of commodities and non-commodities (if already possible because they will compete for the same production factors, in particular land). Further if jointness exists, an examination of the extent to which it is related to the choice of farming system and technology (and to what extent these relationships can be changed) is required (see also Section 2). 


\section{Evidence about the multifunctionality of agriculture}

Although Sections 2 and 3 indicate that there exists a lot of literature addressing the multifunctionality of agriculture from a theoretical or analytical point of view, less studies exist that give empirical evidence on the actual contribution of agriculture to different social values. This fourth section therefore tries to give an overview of what can be found in literature with regard to this. We are conscious that this review is not complete and that probably other references exist complementing our findings. The fact that such a comprehensive study is missing and literature is in general scattered and not very precise shows not only a lack of empirical research in this area but also that this kind of research is not easy. This can partly be explained by the fact that although a lot of methodologies exist to measure non-market values, it remains difficult to estimate the non-market contributions of agriculture either because of lack of good databases or because wider application of the methodologies is cumbersome, difficult and/or expensive.

Two main approaches can be distinguished in assessing the non commodity values of agriculture: a more direct approach as used in ecological sciences trying to measure the physical outcomes (e.g. the biodiversity or quality of amenities) and a more social science approach trying to estimate the contribution to the utility of people either indirectly (e.g. hedonic pricing) or directly by asking people (for an overview see Randall, 2002; Vanslembrouck and Van Huylenbroeck, 2005). Although often criticised (Kahneman and Knetsch, 1992; Jacobs, 1997; Spash, 2000, 2002; Kumar and Kumar, 2004; Zhang and Li, 2005; Howarth and Wilson, 2006) the social valuation method results are often the only ones existing.

On the supply side (positive approach towards multifunctionality) evidence of the involvement of (professional) farmers in more multifunctional activities is difficult to gather, precisely because of the complex definition of multifunctionality. Authors such as van der Ploeg and Roep (2003) give some indication of how many farmers in Europe are involved in different diversification categories such as (1) agri-tourism, on-farm processing activities, nature and landscape management, (2) organic farming, high quality production and regional products or selling through a short supply chain (Figure 5). Their numbers vary between $30 \%$ of all farmers in the U.K. to $59 \%$ of all farmers in Germany. Similar research done in Belgium (in the fringe of Brussels and the coastal area, respectively a densely and less populated area) shows that $19 \%$ of all farmers are involved in some kind of diversification and $11 \%$ are active in nature or environment conservation (Vandermeulen and Van Huylenbroeck, 2006a). Both studies also reveal that the decision of a farmer to diversify depends not only on location or regional characteristics, but also on the characteristics of the farm and farmer himself. It appears that some farm types are much more appropriate to have multifunctional activities than others (Gilg and Battershill, 1999; McNally, 2001; Vanslembrouck et al., 2002; Loureiro and Jervell, 2005; Jongeneel et al., 2005). However, although the figures cited above are linked to multifunctionality, they do not really measure the amount of non-commodity outputs produced (see the distinction between diversification and multifunctionality in Section 2). This amount can only be assessed by looking at the demand side.

On the demand side more evidence is published. This evidence can be categorised according to the economic, social and environmental function (Hall and Rosillo-Calle, 1999).

- The economic function: agriculture remains a principal force in sustaining operation and growth of the whole economy, even in highly industrialised countries. Valuation of the various economic functions requires assessment of short, medium and long-term benefits. Important determinants of the economic function include the complexity and maturity of market development and the level of institutional development.

- The social function: the maintenance and dynamism of rural communities is basic to sustaining agro-ecology and improving the quality of life (and assuring the very survival) of rural residents, particularly of the young. On another level, the capitalisation of local knowledge

Living Reviews in Landscape Research

http://www. livingreviews.org/lrlr-2007-3 


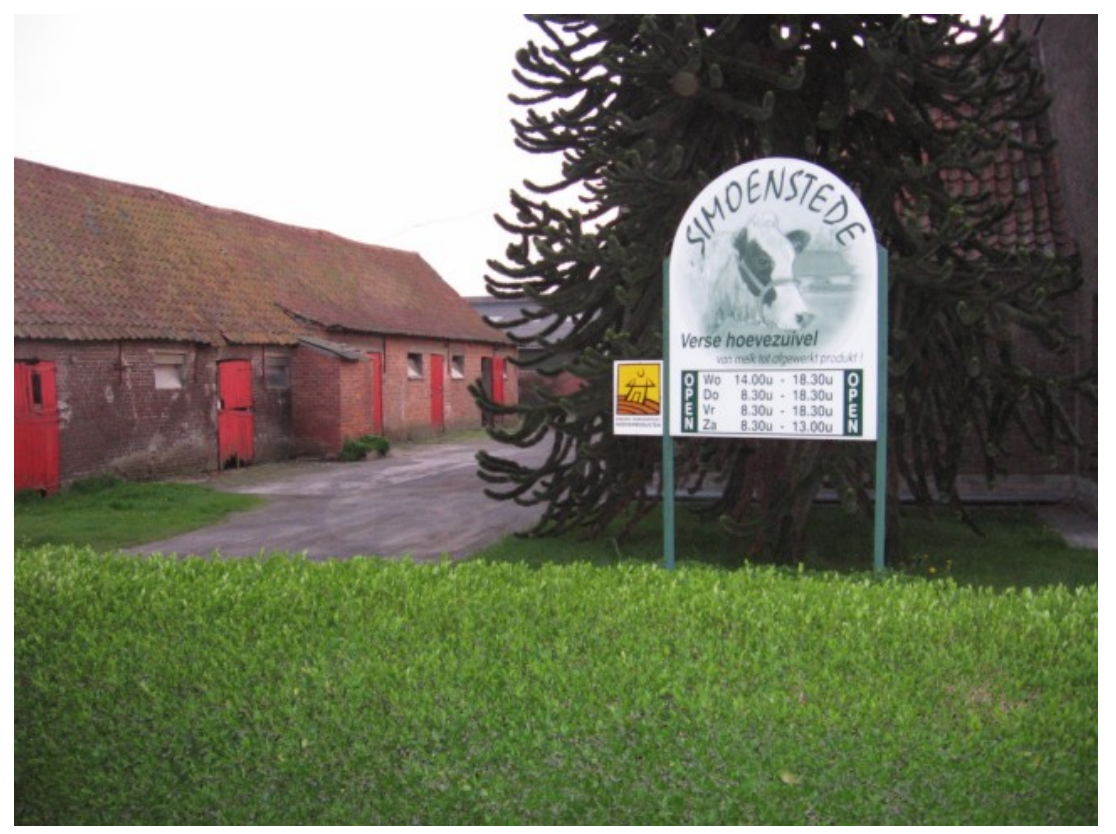

Figure 5: Example of farm sales in Flanders.

and the forging of relationships between local and external sources of expertise, information and advice are fundamental to the future of existing rural communities. Social viability includes maintenance of the cultural heritage. Societies still identify intensely with their historical origins in agrarian communities and rural lifestyles.

- The environmental function: agriculture and related land use can have beneficial or harmful effects on the environment. The multifunctional approach can help to identify opportunities to optimise the linkages between agriculture and the biological and physical properties of the natural environment. It is relevant to a number of critical global environmental problems including biodiversity, climate change, desertification, water quality and availability, and pollution.

The three functions are clearly interrelated. Their relative importance will depend on strategic choices at the local and national levels. The multiple functions may as already indicated be relevant at many scales, from local, over national and regional, to global, and operate over different horizons - indeed some innovations and transformations may have short-term disadvantages, such as lower productivity, before leading to longer-term, overall economic and environmental benefits. This also explains the difficulty to find empirical evidence.

\subsection{Economic function}

With respect to the economic values we concentrate on the indirect economic benefits of noncommodity production. These are mainly captured by other stakeholders such as inhabitants of rural areas, the real estate sector, the tourism sector or other economic agents in rural areas such as drinking or bottled water companies or companies using the image of rural areas in their publicity or marketing. Most evidence about spill-over effects of agriculture exists with respect to real estate values and rural tourism. Not included in our overview are benefits captured by the food sector 
that also may capture extra rents from territorial or labelled products as we assume these benefits are partly transferred to farmers in the prices of primary agricultural products.

Empirical results from literature show that the presence of agriculture and in particular of agricultural amenities has a positive influence on real estate values (housing sector). Using hedonic pricing methods Garrod and Willis (1992), Cheshire and Sheppard (1995), Irwin (2002), Tyrväinen and Miettinen (2000) Irwin and Bockstael (2001) and Ready and Abdalla (2005) among others, give empirical evidence that a landscape consisting of agricultural open space increases nearby residential property values. The numbers obtained highly differ according to the research method, the area, the hypotheses, the agricultural amenities considered, the data set used and so on. But in general, the existing literature shows that more extensive forms of agriculture (farmland, grassland) have a positive influence while intensive forms of agriculture (large animal or mushroom farms) reduce nearby property values (Palmquist et al., 1997). Geoghegan (2002) shows for Maryland (U.S.A.) that, although the presence of agriculture nearby housing increases in general the willingness to pay higher prices for a house, permanent farmland has the highest positive impact. He defines permanent farmland as land owned by a farmer who has sold his development rights. Roe et al. (2004) are more convinced that it is not the difference between permanent and developable land that explains the pull effect of farmland on household location decisions, but the individual's trade-off between rural amenities and other attributes of housing and location.

Second, there is clear evidence that the rural tourism sector captures some benefits of agriculture (Figure 6). Rural tourism is increasing and able to persuade every year a higher number of people (Roberts and Hall, 2001; Garrod and Whitby, 2005). Hedonic price analyses of rural accommodation show the clear link between the presence of agricultural amenities in the landscape and the price that can be charged to rural tourists. This is indicated inter alias by some recent studies of Fleischer and Tchetchik (2005) and Vanslembrouck et al. (2005) who show that prices of rural accommodation are significantly higher in areas with more agricultural amenities. An interesting study is also the study of Fleischer and Tsur (2000) who show for two regions in Israel that of the total estimated consumer surplus of rural tourism $10 \%$ to $20 \%$ is generated by the presence of agricultural landscapes. Their estimates also reveal that the landscape value of farmland is far in excess of the commodity returns in farming. An even more positive result was discovered by Chang and Ying (2005) through a contingent valuation method resulting in households willing to pay about 3.57-fold of the intrinsic economic value of rice for sustaining paddy fields in Taiwan. Although such studies can be criticized as overestimating these values, they indicate at least that there are positive spill-over effects of agriculture on tourism. Part of these benefits can be captured by farms offering farm accommodation or engaged in direct selling or marketing of regional products. In a recent study for the coastal area of Belgium we found that over $5 \%$ of total income in the farming sector comes from diversification activities of which a major part is linked to agro-tourism and direct selling (Van Huylenbroeck et al., 2006).

On other spill-over effects such as the rents captured by firms using territorial images there is no clear evidence available, but such economic rents exist as is proven by the number of cases in which agricultural landscapes are used for image building and this not only in the food sector, but also in other sectors. Of course such spill over effects require a suitable region with a certain (potential for creating a) territorial identity and are therefore less valid for highly remote or unattractive areas. To a certain extent, the same holds for the social functions discussed in the next section.

\subsection{Social function}

With respect to social values, most empirical research concerns rural viability. It is shown that, in general, agriculture contributes to rural viability and might revitalise rural areas (Sharpley and Vass, 2006). This has been studied either through general surveys on what citizens expect from agriculture or appreciate in rural areas or through more specific contingent valuation studies

Living Reviews in Landscape Research

http://www. livingreviews.org/lrlr-2007-3 


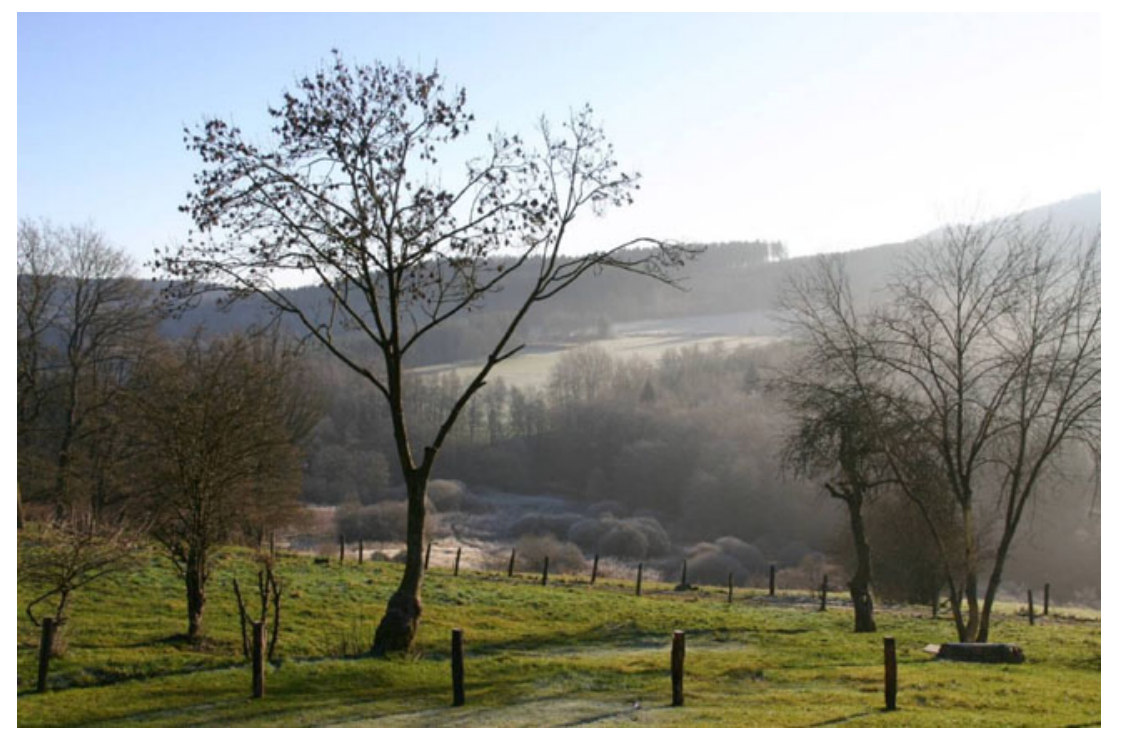

Figure 6: View on an agricultural landscape in the touristy Belgian Ardennes.

estimating people's willingness to pay for the maintenance of farming in rural areas. Hall et al. (2004) give a nice meta-analysis overview of what the public expects from agriculture and the countryside. Most studies reviewed indicate that respondents see a definite role of agriculture as an intrinsic value provider of rural environmental goods, cultural heritage and expect a contribution to safe food, environmental conservation, landscape amenities and so on. Also an own study (Van Huylenbroeck et al., 2005) shows that citizens, in particular the higher educated part, value the positive contribution of agriculture in rural areas. A number of studies also tried to measure the economic willingness-to-pay for the presence of farming in rural areas. Poe (1999) gives an overview of studies in the U.S. showing that all studies indicate a positive value ranging from 7 US\$ to 252 US\$. Bennett et al. (2004) use the Choice Modelling technique to estimate the society's willingness to pay for maintaining viable rural communities in Australia. They found that respondents are willing to pay an implicit price to prevent farmers to leave the agricultural sector related to the positive contributions to the viability of rural areas. Hyytiä and Kola (2006) come to the conclusion that an important proportion of Finnish citizens have a positive attitude towards externalities and joint products of agriculture. Also a Spanish study (Kallas et al., 2007) shows in a Choice Experiment that citizens of Tierra Campos in Spain are willing to pay for agricultural multifunctionality. They found positive signs for employment in the agricultural sector and for the percentage of farmers living in the area. Many of these studies also reveal that the willingnessto-pay increases with shifts to more multifunctional farming systems (e.g. integrated or organic farming) or that there is an extra willingness-to-pay for specific services (e.g. Moon et al., 2005).

There are further indications that agriculture can have a significant contribution in the health sector as contact with nature and farming is shown to have a positive effect for disabled persons or people with mental or psychological problems (see Di Iacovo, 2003).

Other evidence of the increasing societal interest in multifunctional attributes from agriculture comes from emerging and expanding markets for products from alternative production systems, (e.g. organic farming) the growth of regional labels and the growing interest in initiatives promoting local agriculture (e.g. community agriculture or local food teams) (Batie, 2001). 


\subsection{Environmental function}

And last but not least, sustainable agriculture does not only contribute to economic and social viability, but also provides environmental values by conserving agri-ecological and agro-environmental systems, which have an impact on society as a whole. Brodt et al. (2006) show that the link between these last two aspects of sustainability is not often studied. Even more, the ecological impact of multifunctional agriculture is not much studied in literature and hard data are scarce. It is clear of course that intensification of agriculture has caused negative externalities on the environment and biodiversity (e.g. by reducing habitat heterogeneity as shown by Benton et al., 2003). On the other hand, there is also evidence that a withdrawal of agriculture has a negative impact on landscapes and agri-ecological systems (MacDonald et al., 2000). Although there is a general believe that agrienvironmental schemes (AES) and conservation practices are contributing to the maintenance of agricultural ecosystems, it is difficult to assess the success of AES because monitoring their impact has generally been poor (Kleijn and Sutherland, 2003). However, when appropriately designed and targeted (Evans et al., 2003), such schemes are capable of providing measurable benefits to wildlife populations over wide geographical areas (an overview is given in Donald and Evans, 2006). Field margins, hedgerows, pollard willows, and other non-crop habitats that are important elements of agricultural landscapes have different ecological benefits (Figure 7). They support more diverse invertebrate communities (Denys and Tscharntke, 2002), provide important nesting and feeding habitat for birds (Fuller et al., 2004), serve as corridors or islands to facilitate the dispersal of birds (Hinsley and Bellamy, 2000), result in greater floral diversity (Swetnam et al., 2004; Marshall et al., 2006) and reduce herbicide drift (Aude et al., 2004). Furthermore, there is also evidence that multifunctional agriculture may contribute to a solution for carbon sequestration (West and Marland, 2003), flood control and water conservation (Mitsh and Gosselinck, 2000; Scrase and Sheate, 2005).

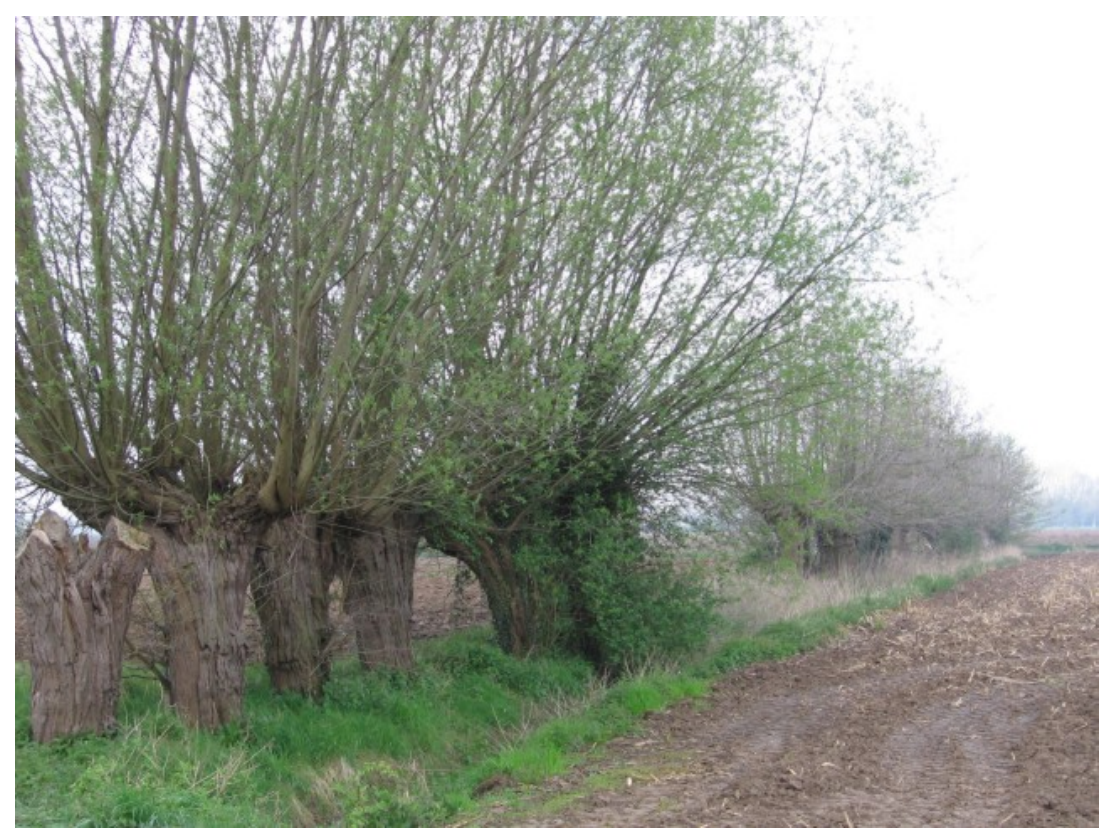

Figure 7: A row of pollard willows on the edge of an agricultural parcel in Belgium.

Although the above overview is probably not complete and not overwhelming - there is certainly a need for more empirical research in this area - the evidence given shows that agriculture has

Living Reviews in Landscape Research

http://www. livingreviews.org/lrlr-2007-3 
both directly and indirectly important contributions to the welfare of society and thus a role in the maintenance of rural areas. However, most studies also indicate that this requires a shift in farming systems, practices and models. It is generally accepted that intensive and large scale production systems contribute less to non-commodity production than more extensive and adjusted scale production systems (see e.g. Gibson, 2005, for grassland systems). However intensification and scale expansion will continue in a liberalizing market where non-tradable outputs are not valued. The question is then whether other strategies, policies and farming models exist, able to create incentive systems for a multifunctional agriculture and a restructuring of the farming sector towards a more socially desirable production model and output bundle. This does not mean that farming systems need not to be competitive but it means that we need to find public or private arrangements in which efficiency and competitiveness are measured not only in terms of tradable but also in terms of non-tradable outputs. Therefore, in the next Section 5 we first review what multifunctionality can mean as a policy paradigm. Next we give some thoughts on institutional network arrangements and rural development discourses that could be used to stimulate multifunctional farming practices. 


\section{$5 \quad$ Multifunctionality as a policy paradigm}

\subsection{Shifting policy paradigm}

Moyer and Josling (2002) call multifunctional agriculture a third agricultural policy model or paradigm (Table 1) that has the potential to replace the old dependent model and the present competitive model advocated by the U.S. and the WTO. Although the old model has been very successful in increasing commodity production, it has showed its limits due to market problems, problems of unfair competition, ecological problems and social problems. The competitive or liberalisation paradigm believes that competition leads to the best allocation of resources and low costs. Public intervention is only seen as risk management with some safety nets in case of serious disturbed markets or sanitary or other problems. The problem is that not all produced outputs are market goods but that there are joint products that risk to disappear in markets only remunerating the commodity aspects of food. World market prices are seen as only reflecting the commodity production costs and not the extra costs linked to the provision of the non-tradable public goods. Blind liberalisation may therefore lead to the disappearance of farming systems which, as was discussed earlier, are superior in the production of (local) public goods. Therefore, Moyer and Josling (2002) support the idea of a new paradigm focussing on protection of other functions of agriculture. Also Potter and Burney (2002) and Potter (2006) conclude that, although multifunctionality is a genuine, but in some respects, unique, feature of European agriculture, it receives its full meaning in relation to the perceived threat of extensive agricultural restructuring to biodiversity and landscape values. They think the concept has profound implications for policy design, suggesting a need to retain some element of income support in the policy mix in order to defend environmental assets against the extreme consequences of farm structural change.

Also in the social sciences literature multifunctionality is regarded as a possible new paradigm or regime for agriculture (van der Ploeg and Roep, 2003; Wilson, 2004). They relate the multifunctional model to a new agri-food system with new relations between producers and consumers. The concept in their view refers to quality food chains that are fully embedded (socially, culturally and ecologically) in the local territory. In this model agriculture plays a pivot role and is a driver for rural change, transition and development (Knickel and Renting, 2000; Marsden et al., 2002). Farmers are much more seen as rural entrepreneurs who combine a number of farm and non-farm activities partly paid by commodity markets and partly by government markets. An extensive review by van der Ploeg and Roep (2003) revealed that already a large part of farmers gain income from non-farm activities. They argue for higher added value markets (local quality products) and more attention for the contributions of farming to the environment, the local culture and so on. However, other authors are more sceptical about the new model (Burton and Wilson, 2006). Their study questions the idea that any transformation from productivism to post-productivism and multifunctionality will be in the form of a simple linear transition. Results from a survey of farmers in Bedfordshire (U.K.) and evidence from other studies throughout Europe and Western agricultural regimes demonstrate that - despite much talk of an increasing 'conservationist' component to farming - farmers' self-concepts are still dominated by production-oriented identities. They conclude, therefore, that there is a temporal discordance between the macro- and micro-structural elements implied in the multifunctional model, and that we are witnessing at most a partial macro-structural driven transition towards a post-productivist agricultural regime. Other authors also acknowledge that some farmers are more likely to switch to multifunctional agriculture than others. As was mentioned before, some farm types are more appropriate to develop multifunctional activities then others (inter alias Gilg and Battershill, 1999; McNally, 2001; Vanslembrouck et al., 2002; Loureiro and Jervell, 2005; Jongeneel et al., 2005). Even more, some others, inter alias van der Ploeg and Roep (2003) and Schmitzberger et al. (2005), indicate the importance of farm responses, farming styles and farmer behavior on the process. They found that farms who are less cost oriented seem

Living Reviews in Landscape Research

http://www. livingreviews.org/lrlr-2007-3 
Table 1: Competing paradigms in agricultural policy (adapted from Moyer and Josling, 2002, p. 32).

\begin{tabular}{|c|c|c|c|}
\hline & Dependent & Competitive & Multifunctional \\
\hline & Old paradigm & $\begin{array}{l}\text { New paradigm, used } \\
\text { in the U.S. }\end{array}$ & $\begin{array}{l}\text { New paradigm, used } \\
\text { in the EU }\end{array}$ \\
\hline $\begin{array}{l}\text { Nature of agricul- } \\
\text { ture }\end{array}$ & $\begin{array}{l}\text { - Low incomes } \\
\text { - Not competi- } \\
\text { tive with other } \\
\text { sectors } \\
\text { - Not competi- } \\
\text { tive with other } \\
\text { countries }\end{array}$ & $\begin{array}{l}\text { - Average incomes } \\
\text { - Competitive } \\
\text { with other sec- } \\
\text { tors } \\
\text { - Competitive in } \\
\text { world markets }\end{array}$ & $\begin{array}{l}\text { - Incomes from } \\
\text { farming inade- } \\
\text { quate } \\
\text { - Producer of } \\
\text { underrewarded } \\
\text { public goods }\end{array}$ \\
\hline Policy objective & $\begin{array}{l}\text { - Government } \\
\text { needed to find } \\
\text { markets } \\
\text { - Supply control } \\
\text { necessary }\end{array}$ & $\begin{array}{l}\text { - Move towards } \\
\text { free market } \\
\text { - Relax supply } \\
\text { control }\end{array}$ & $\begin{array}{l}\text { - Preserve coun- } \\
\text { tryside } \\
\text { - Keep family } \\
\text { businesses viable }\end{array}$ \\
\hline Policy instruments & $\begin{array}{l}\text { - Border protec- } \\
\text { tion } \\
\text { - Surplus buying } \\
\text { - State trading } \\
\text { - Export assis- } \\
\text { tance }\end{array}$ & $\begin{array}{l}\text { - Decoupled pay- } \\
\text { ments in transi- } \\
\text { tion } \\
\text { - Risk manage- } \\
\text { ment } \\
\text { - Low safety-nets }\end{array}$ & $\begin{array}{l}\text { - Environmental } \\
\text { subsidies } \\
\text { - Protection } \\
\text { against "mono- } \\
\text { functional" agri- } \\
\text { culture } \\
\text { - New institu- } \\
\text { tional arrange- } \\
\text { ments } \\
\text { - Rural develop- } \\
\text { ment plans }\end{array}$ \\
\hline
\end{tabular}


to be more susceptible to switch their farming system and to incorporate other functions in their behavior. The farming styles concept could therefore be an interesting research area to analyze the link between farmers' behavior and multifunctionality.

Although the concept of the multifunctionality paradigm has highly been contested and debated (Anderson, 2000; Holmes, 2002; Walford, 2003; Potter and Tilzey, 2005) it has become a leading paradigm for creating a framework for explaining policy actions, mainly in Europe inter alias because of the declaration in 2000 of the European Ministers of Agriculture that:

"The fundamental difference between the European model and that of our main competitors lies in the multifunctional nature of agriculture in Europe and in the role it plays in the economy and the environment, in society, and in the conservation of the countryside; hence the need for maintaining agriculture all over Europe and protecting farmers' income." (Agenda 2000, 1998)

The European Model of Agriculture, as Potter (2006) mentions, has further developed to a bimodal model by creating a beneficial environment for producers with the potential to compete at the world market and by supporting producers in marginal locations to supply nature, leisure and niche products through rural development plans and direct income support. This multifunctionality model allows for payments compensating the increased costs of production systems that effectively produce social values which are not valued by food or related markets.

Much of the economic literature and debate with respect to multifunctionality as policy term is related to trade issues. This literature was particularly large at the start of the Doha round of WTO with heavy debates between supporters and opponents of the concept. A nice overview of the viewpoints concerning the trade aspects at that moment is given by Burrell (2001, 2003). A key concern was whether attempts to protect multifunctional attributes are merely disguised barriers to trade (Blandford, 1999; Bohman et al., 1999; Orden et al., 1999; Dobbs and Pretty, 2001; Blandford and Boisvert, 2002). Supporters mainly emphasize the non-tradability of noncommodity outputs and therefore argue that protection of farming systems which are superior in the production of non-commodities deserve protection (Gallardo et al., 2003).

Some authors, such as Wilson (2001), Van Huylenbroeck and Durand (2003) and Knickel and Renting (2000), have taken away the concept from the direct policy debate and demonstrate that it has some grounded conceptions to encompass ideas on the restructuring of the farming sector. As we have demonstrated in Section 4, some farming systems can be superior in their combination of market and non-market goods than others (maybe linked to their farming style as mentioned above). The question is then how to stimulate the transition to such systems. One main misunderstanding is that the multifunctionality concept is a disguised argument for income support to non-efficient farmers. This does not need to be so, on the contrary, multifunctionality as a concept does not refuse efficiency but only suggests to measure efficiency not merely in profit terms but also in terms of socially desired outcomes (Van Huylenbroeck and Durand, 2003). Farmers have to be stimulated to search for new markets in which they may have a competitive advantage either because of their social superior outcomes (such as higher value markets, local products, food products for agri-tourists) or because of their efficiency in what we can call public markets: the delivery of outputs for which the state is (partly) paying (such as agri-environmental outputs, green care, health services and so on).

Multifunctionality policies therefore have only to correct for missing markets and stimulate rural entrepreneur companies either individually or in group (territories) to finding unique selling and delivery positions and income combinations. Where necessary, multifunctionality policies should organise public markets for non-tradable goods and facilitate new rural coalitions or networks based on new arrangements between the private and public sector, in such a way that they stimulate the most efficient providers and not only provide income support systems to non-efficient farms. A multifunctionality policy is in other words not equivalent to an income support policy to less competitive farms that otherwise can not survive, but stimulates efficient provision of local public goods.

Living Reviews in Landscape Research

http://www. livingreviews.org/lrlr-2007-3 


\subsection{Policies and instruments in the multifunctionality paradigm}

We will in this contribution not discuss or try to summarize the literature on possible policies and instruments for public good provision (see, inter alias Hanley et al., 2006) but rather we schematise based on Van Huylenbroeck and Slangen (2003) and Van Huylenbroeck (2005) a number of possible arrangements going from private-private arrangements in the food market (e.g. regional labels in the food industry) or in other markets (e.g. coalitions or contracts between tourism or water supply sector and farmers) over coalitions with NGOs (e.g. with wild life trust or nature conservation organisations) or even private users interested in non-commodity products (e.g. hunters), to new arrangements with the public sector, either more regulative or through the creation of new markets such as e.g. the pricing of agri-environmental outputs or the production of 'green' energy (Figure 8).

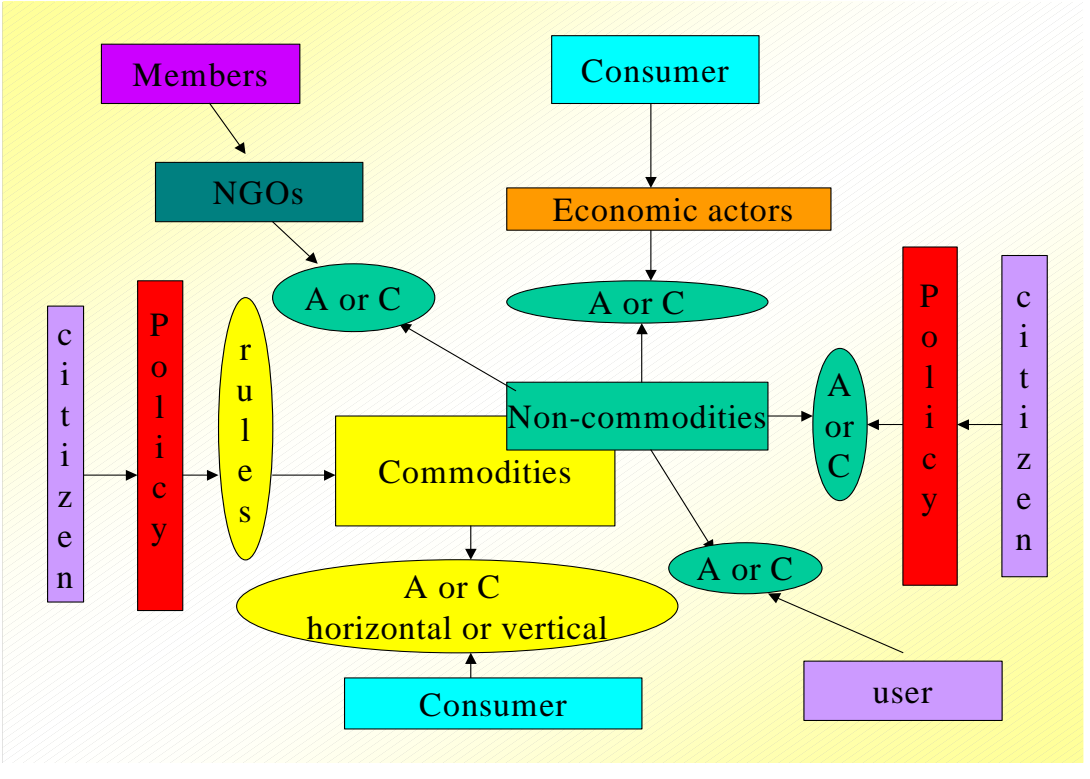

Figure 8: Intermediate institutions ( $A=$ arrangements and $C=$ Coalitions) to deliver a changed commodity-non commodity output bundle (see Van Huylenbroeck, 2005, for more explanation).

Most of these forms of cooperation or alliances can not only have a positive effect in the case of the supply of private goods, but also in the supply of impure public goods like wildlife and landscape. The Dutch case of environmental cooperatives (Polman, 2002), that organises agrienvironmental schemes for a group of farmers, is a good example of such an arrangement. From an institutional economics point of view these cooperatives are a way to cope with market failure, save on transaction costs, build up countervailing power, provide an alternative to government intervention and prevent hold-up problems (Polman, 2002). One can as well suspect some environmental benefits from this kind of organization because the territorial scale on which they operate is larger than the individual farm scale. Dutch research in national landscapes concluded that cooperation of different land owners, such as farmers, nature and landscape managers, recreation operators and other rural people leads to more combined functions and a better and broader infrastructure (Overbeek and Terluin, 2006). This could lead to what Merlo (2001) calls rural entrepreneurs or a kind of 'partnership' type of rural company active in food and fibre production, but also in the maintenance of the countryside, offering recreational services and so on. Such partnership type of company could consist of farmers, municipalities, environmental NGO's, consumer and other organizations and individual citizens. Individual farms are still recognizable, but the responsibilities are shared in the collective organization (Stedula, 2004). An emerging example is the 
Stadteland Cooperation in the Netherlands in which rural managers (producers) and consumers of agricultural products in the broadest sense participate (de Lauwere et al., 2006). Besides typical agricultural partnerships, one can also think about partnerships between agriculture and other local stakeholders who profit from multifunctional agriculture. An example of this is the VITTEL case in France where the water company has closed a partnership contract with farmers in its water source area (Nestlé, 2006). We may also investigate possibilities of new forms for financing the provision of public goods, such as a rural tourism or real estate tax for remunerating farmers for their contribution to landscape amenities, water management, flood control and so on. Portrait rights could be a solution for alliances at the territorial level between farmers and companies using the local-agrarian identity to create added value.

The last point brings us to the regional or territorial scale. Food regions will more and more compete on the basis of local identities and added value creation in the high segment food market. As illustrated in Table 2 coherent planning and policy discourses can be developed depending on the strengths and opportunities in a region while taking into account the added value of production systems for the environment, the local economy and social cohesion (Allaert et al., 2006).

In areas with a still competitive commodity producing agriculture, planning and policy will mainly aim at bringing the agricultural sector more in line with the constraints of a peri-urban zone. These policy objectives can then be translated into incentives to push farms and agro-industry to invest in higher value chains so that agriculture (and also the non-commodity production linked to his) becomes less dependent on world commodity markets and thus less vulnerable. This may be combined with agri-environmental contracts. An example of the Dutch cheese brand 'Beemster' for which the CONO dairy co-operative gives an extra premium to dairy farms in the Beemster region who meet certain environmental standards. This leads in turn to milk with higher quality and enables the co-operative to sell the processed cheese at a higher price (Oerlemans and Hees, 2006). For regions with a strong agri-business network based on contractual relations with local industry - e.g. the Flanders Vegetable Valley in the coastal area of Belgium (Vandermeulen and Van Huylenbroeck, 2006b) - the competitiveness of the agro-industrial network can be strengthened by increasing the territorial embedding. This would result in an agri-business complex which is more dependent on local resources and thus more difficult to be relocated to lower cost production regions. Areas with strong territorial advantages may further exploit these advantages by bringing in more agro-ecological elements and vertical linkages so that wider markets can be reached. This can be done by combining the territorial complex with an agro-industrial complex or by strengthening ecological elements in the production (e.g. switching to organic farming). A good example of this is the 'Parmigiano-Reggiano Cheese' in Italy in which many farmers, cheese dairy and ripening firms have succeeded in developing a high quality cheese production with less pressure on the environment (de Roest and Menghi, 2000). Lastly, also regions with important or sensitive ecological networks may learn from territorial approaches to strengthen the marketing of ecological products (eventually combined with rural tourism). An example of how organic production and ecological networks can lead to economic benefits for farmers is the dairy production in mountainous regions in Austria, Switzerland, or Italy (Figure 9). These farmers are financially supported by the government, but also benefit from a good cooperation with supermarket chains (Milestad and Hadatsch, 2003). These are only a few examples which prove that multifunctionality can go hand in hand with industrial or regional strategies and might be a powerful strategy to safeguard local agricultural production and at the same time local public goods. Territorial and ecological embeddedness (for the development of the concept see, inter alias, Penker (2006) and Kirwan et al. (2007)) is therefore not only interesting as a concept for contextualising multifunctionality but also a promising area for future research in rural economy and rural geography. Competitiveness of local agro-food and territorial systems will indeed become a more important concept for the rural future than the competitiveness of individual farms. Research in the densely populated and urbanised fringe around Brussels proves that the local level instruments can indeed make a difference in

Living Reviews in Landscape Research

http://www. livingreviews.org/lrlr-2007-3 
Table 2: Multifunctional development models (adapted from Allaert et al., 2006).

\begin{tabular}{|c|c|c|c|c|}
\hline $\begin{array}{l}\text { Development } \\
\text { models }\end{array}$ & 1 & 2 & 3 & 4 \\
\hline $\begin{array}{l}\text { Policy } \\
\text { paradigm }\end{array}$ & Competitive & \multicolumn{3}{|c|}{ Multifunctional } \\
\hline $\begin{array}{l}\text { Planning dis- } \\
\text { course }\end{array}$ & Production space & $\begin{array}{l}\text { Network of activi- } \\
\text { ties }\end{array}$ & $\begin{array}{l}\text { Network of locali- } \\
\text { ties }\end{array}$ & Ecosystem \\
\hline $\begin{array}{l}\text { Main agricultural } \\
\text { model }\end{array}$ & $\begin{array}{l}\text { Industrialised, } \\
\text { large scale com- } \\
\text { modity producing } \\
\text { agriculture }\end{array}$ & $\begin{array}{l}\text { Agri-business } \\
\text { complex exploit- } \\
\text { ing local compar- } \\
\text { ative advantages }\end{array}$ & $\begin{array}{l}\text { Local food sys- } \\
\text { tems with diversi- } \\
\text { fication }\end{array}$ & $\begin{array}{l}\text { Ecological farm- } \\
\text { ing systems }\end{array}$ \\
\hline $\begin{array}{l}\text { Main market for } \\
\text { products }\end{array}$ & $\begin{array}{l}\text { World commodity } \\
\text { market }\end{array}$ & $\begin{array}{l}\text { Identified world } \\
\text { markets for value } \\
\text { chains }\end{array}$ & $\begin{array}{l}\text { Local food mar- } \\
\text { ket }\end{array}$ & $\begin{array}{l}\text { Specific markets } \\
\text { for integrated and } \\
\text { organic produce }\end{array}$ \\
\hline $\begin{array}{l}\text { Regional ap- } \\
\text { proach }\end{array}$ & $\begin{array}{l}\text { Not, individual } \\
\text { producers organ- } \\
\text { ised per sector }\end{array}$ & $\begin{array}{l}\text { Regional agribusi- } \\
\text { ness complex } \\
\text { with contractual } \\
\text { linkages }\end{array}$ & $\begin{array}{l}\text { Regional iden- } \\
\text { tity with regional } \\
\text { labelling }\end{array}$ & $\begin{array}{l}\text { Local agro- } \\
\text { ecological system }\end{array}$ \\
\hline $\begin{array}{l}\text { Possible con- } \\
\text { straints }\end{array}$ & $\begin{array}{l}\text { Competitiveness } \\
\text { at world market } \\
\text { (competition with } \\
\text { low cost produc- } \\
\text { ers) }\end{array}$ & $\begin{array}{l}\text { Competitiveness } \\
\text { at world market } \\
\text { of value chain } \\
\text { (relocation of in- } \\
\text { dustry) }\end{array}$ & $\begin{array}{l}\text { Territorial com- } \\
\text { petitiveness (sat- } \\
\text { urated markets) }\end{array}$ & $\begin{array}{l}\text { Competitiveness } \\
\text { in niche markets } \\
\text { (small markets) }\end{array}$ \\
\hline $\begin{array}{l}\text { Sustainability } \\
\text { stakes }\end{array}$ & $\begin{array}{l}\text { Economic (em- } \\
\text { ployment) }\end{array}$ & $\begin{array}{l}\text { Economic (em- } \\
\text { ployment and } \\
\text { services) }\end{array}$ & Social & Ecologic \\
\hline $\begin{array}{l}\text { Policy to increase } \\
\text { sustainability and } \\
\text { multifunctionality }\end{array}$ & $\begin{array}{l}\text { Strengthening of } \\
\text { local networks } \\
\text { and promoting } \\
\text { higher value pro- } \\
\text { duction }\end{array}$ & $\begin{array}{l}\text { Strengthening of } \\
\text { competitiveness } \\
\text { on basis of terri- } \\
\text { torial resources } \\
\text { (product oriented } \\
\text { rather than scale } \\
\text { oriented) }\end{array}$ & $\begin{array}{l}\text { Strengthening the } \\
\text { regional identity } \\
\text { and creating ver- } \\
\text { tical markets }\end{array}$ & $\begin{array}{l}\text { Creation of lo- } \\
\text { cal food net- } \\
\text { works and non- } \\
\text { commodity mar- } \\
\text { kets }\end{array}$ \\
\hline
\end{tabular}


stimulating multifunctionality and diversification of the production system (Vandermeulen et al., 2006). Hereby the development of indicators linking socio-economic requirements with landscape and territorial potentials may be a promising avenue (Wiggering et al., 2006).

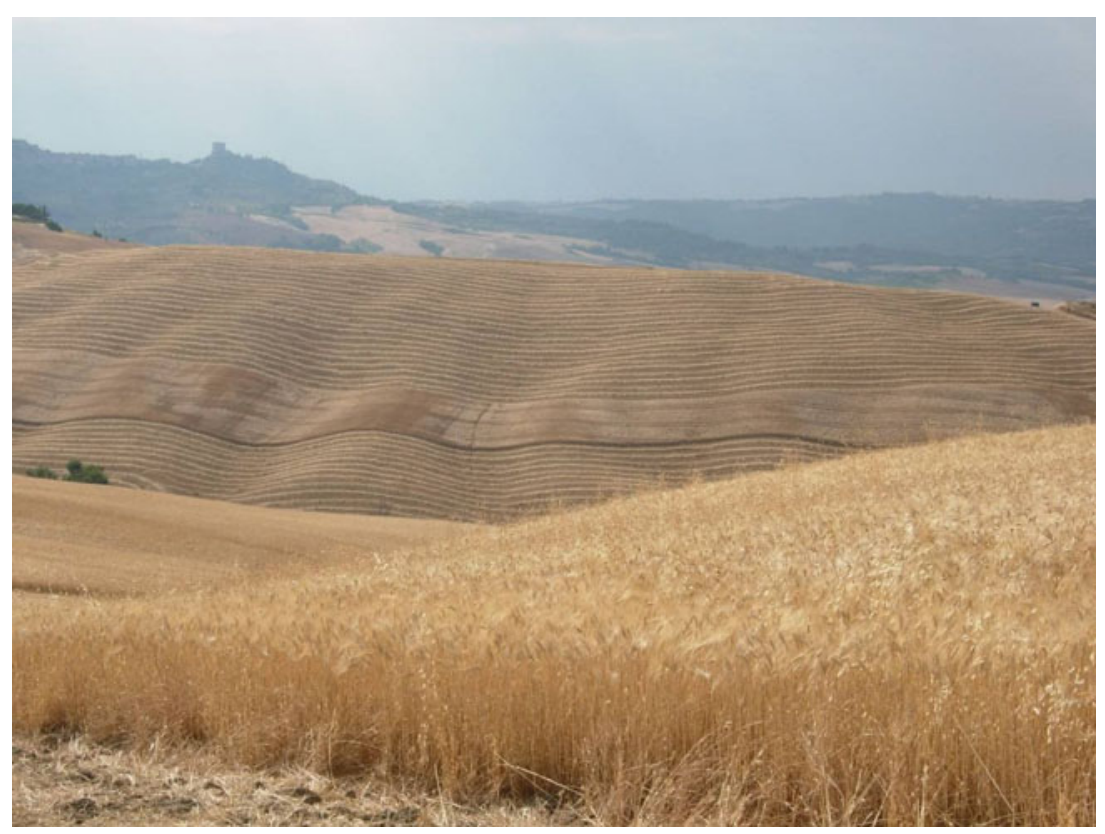

Figure 9: Tuscan landscape with an agricultural character. 


\section{Conclusions}

Farming has a very high potential to exploit multifunctional activities and provide multiple outputs. In particular between farming and rural landscapes a strong joint relation can be found. Any type of farming inevitably has an impact on the landscape. In the past, the skewed remuneration systems in markets made modern farming practices put less emphasis on non-marketable outputs, which were before produced for free (weak disposability). However, because of growing importance of rural areas as consumptive areas, farming should again emphasize this role.

Rather than a bimodal model (Thompson, 2004; Potter and Tilzey, 2005), we see scope for multifunctionality as a unifying concept under which the productive role of agriculture and its role in land management for biodiversity conservation, recreation, water management, climate control and so on can be brought in harmony. By enlarging the definition of competitiveness, production systems efficient in combining several functions can emerge. These can operate either at local markets (both food and non-food), or at international markets. Distinctiveness in markets can be found by unique combinations of resources and values. It is this what is propagated by the term multifunctionality: the fact that specific agricultural systems contribute to distinctive economic, natural, cultural and territorial subsystems. Therefore, we think that by converting the relation and starting the analysis from what makes local rural and farming systems distinctive, we may find clues to build stronger production and food networks which cannot only contribute to rural wealth but bring the existing production system in line with social expectations. In such an approach biodiversity, local identity, cultural heritage and other non-marketable outputs of agriculture become assets with potential value (Marsden et al., 2002) that should and will be protected.

The above ideas correspond with a lot of thinking on agri-food networks or districts (Goodman, 1999; Murdoch, 2000; Marsden et al., 2002; Bertolini and Giovannetti, 2006; Sonnino, 2007) and also encompasses some of the ideas of neo-institutional economics on micro-institutions (Ménard, 2003, 2004) which argue that in agro-food systems the contractual relations and rules of exchange both horizontally and vertically are important for managing food systems.

To further develop the concept of multifunctionality, we agree therefore with G.A. Wilson (Wilson, 2004; Burton and Wilson, 2006) that there is a need to further theoretically underpin and decompose the concept. But, besides theoretical work (according to the lines sketched in this review) we also think there is a need for empirical research. Four major research lines can hereby be distinguished:

1. More empirical research on evidence about the contributions of agriculture in general, and different farming systems in particular, beyond food and fibre production. As shown in this overview the empirical results are still scarce and not really comprehensive. Such research must start from a clear definition (not confusing with diversification e.g.) and clearly distinguish the contributions of conventional production systems from more specific contributions of alternative production systems (such as more extensive farming systems or organic agriculture). This must allow policy indications on how far a shift to such alternative systems and thus reallocation of support is socially desirable.

2. Research on indicators for multifunctionality: if multifunctionality is accepted to have a normative side, it is important to be able to measure in how far individual farming systems or the farming sector in a region or country is approaching the desired level of multiple outputs. This requires the development of indicators measuring the contributions towards desired outcomes. So far notwithstanding a few exceptions (Wiggering et al., 2006; Mander et al., 2007), such indicators are rare. They may differ from usual sustainability indicators in the sense that they need to emphasize the positive role of farming in society. 
3. Research on policy instruments and farm behaviour with respect to multifunctional agriculture. Because the price signal for non-commodity outcomes may be incomplete, it must be corrected by policy instruments to enforce the social desired optimum. Traditional commodity instruments are not adapted to the new outcomes and therefore need to be replaced gradually by newly designed instruments. However, because of the farm and location specific elements of multifunctionality, the individual farm reaction to these instruments becomes a core element as it will be important to know the regional impact of generic but maybe regionally adapted instruments. This requires, as indicated in Buysse et al. (2007) more specific farm modelling and analysis of farm behaviour towards certain policies. Enriching or coupling these models with farm styles research, GIS, multi-agent systems, risk behaviour and so on are promising avenues in this respect.

4. Research on multifunctionality as an asset. As stated before multifunctionality may be regarded as an asset for regional development. Research should show through case studies how such multifunctional farming systems, landscapes or regions can be built on the basis of the assets represented by the joint outputs of these systems. We therefore strongly plea for integrated case study work showing the economic and social value for both individual farms and farming regions of producing non-commodity outputs and to reveal the real value of things such as rural identity and embeddedness both socially and economically. This can evolve in the study of mechanisms to construct, maintain and institutionalise such a multifunctional system.

We conclude with stating that we believe that the conceptual work on multifunctionality in the recent past is only the start for further more theoretical and empirical research to which a lot of disciplines and schools can contribute. Cross fertilisation between the here developed socioeconomic frameworks and the insights of e.g. the ecosystem service or landscape based frameworks would certainly further enrich the insights in the concept. We hope that this contribution is a further step in this direction. 


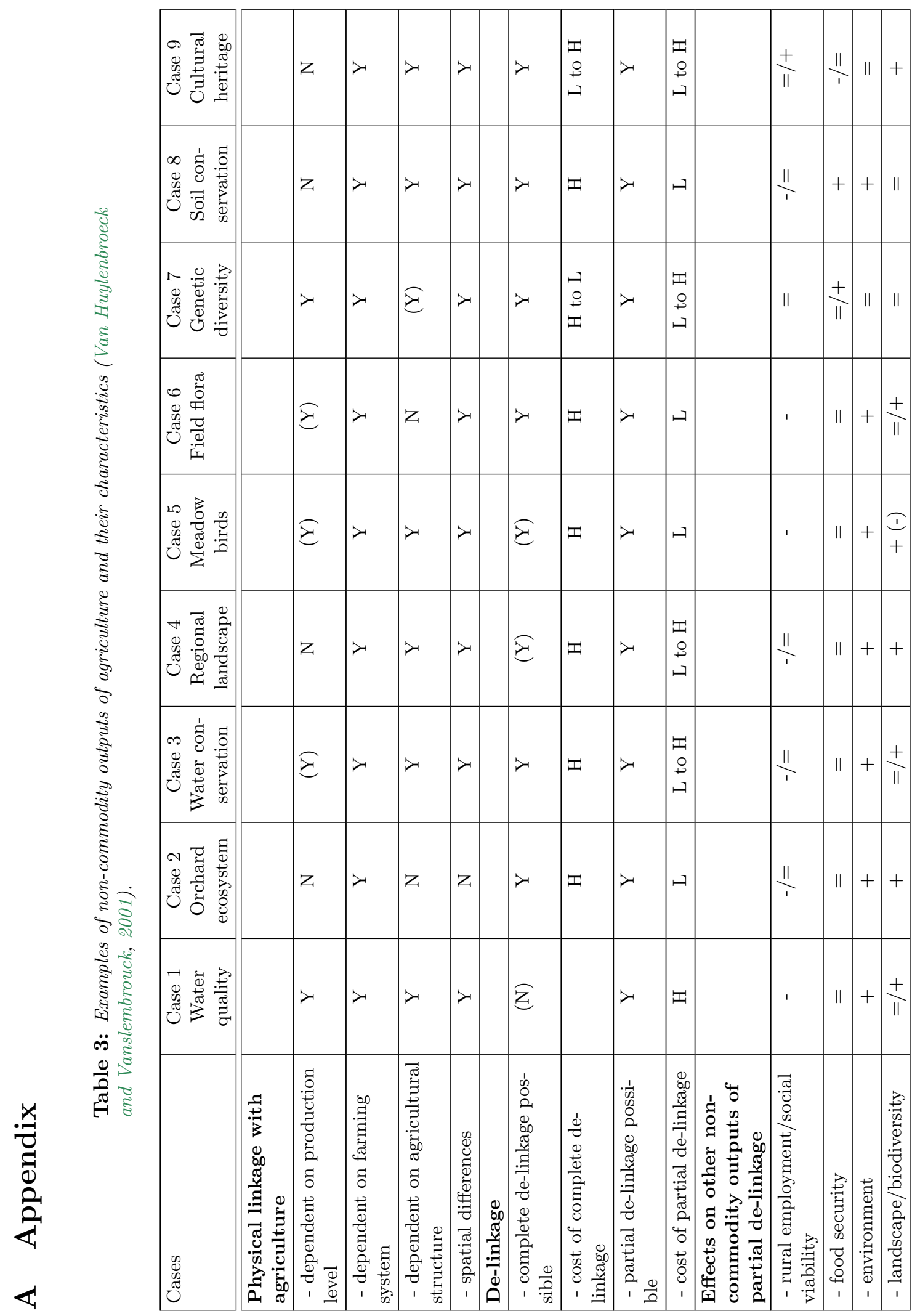



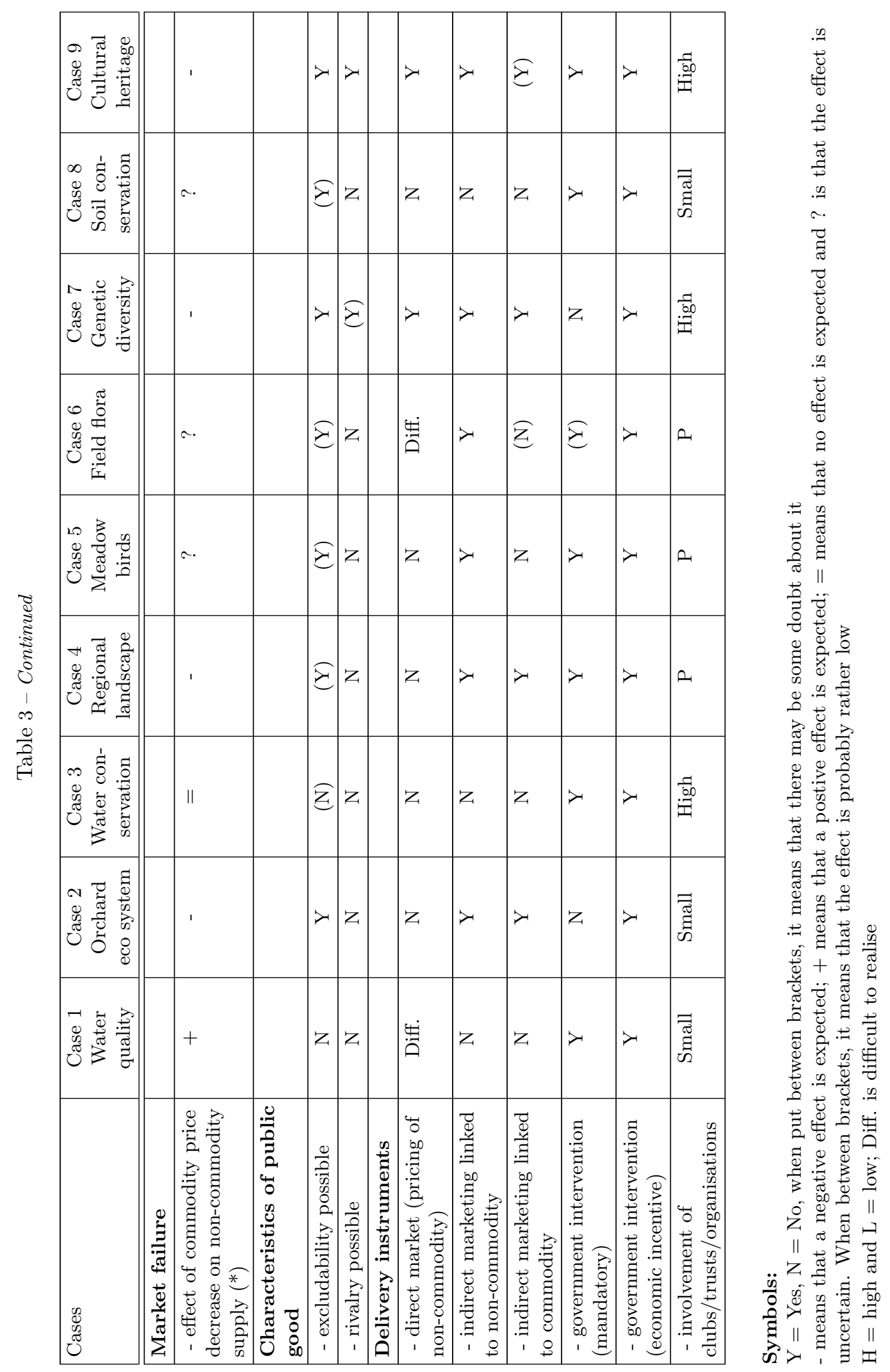


\section{References}

Abler, D. (2001), "A Synthesis of Country Reports on Jointness Between Commodity and NonCommodity Outputs in OECD Agriculture", Workshop on Multifunctionality, Paris, conference paper. Related online version (cited on 23 May 2007):

http://www1.oecd.org/agr/mf/. 3, 3

Abler, D. (2004), "Multifunctionality, Agricultural Policy and Environmental Policy", Agricultural and Resource Economics Review, 33(1): 8-17. 3

Agenda 2000 (1998), "Agenda 2000 - Commission Proposals, Explanatory Memorandum - The Future of Agriculture", Brussels (Commission of European Communities (CEC)). 5.1

Aldington, T.J. (1998), "Multifunctional Agriculture: A Brief Review from Developed and Developing Country Perspectives", unknown status. FAO Agriculture Department, Internal Document. 2

Allaert, G., De Meulder, B., Van Huylenbroeck, G., Van Hecke, E., Meert, H. (2006), "Randvoorwaarden voor duurzaam agrarisch ruimtegebruik in een verstedelijkende netwerksamenleving (Preconditions for sustainable land use by agriculture in urbanising network society)", Brussels (Belgian Federal Science Policy Office). Related online version (cited on 23 May 2007): http://www.belspo.be/belspo/home/publ/rappCPagr_en.stm. 5.2, 2

Anderson, K. (2000), "Agriculture's 'multifunctionality' and the WTO", Australian Journal of Agricultural and Resource Economics, 44(3): 475-494, doi:10.1111/1467-8489.00121. 5.1

Aude, E., Tybirk, K., Michelsen, A., Ejrnæs, R., Hald, A.B., Mark, S. (2004), "Conservation value of the herbaceous vegetation in hedgerows - does organic farming make a difference?", Biological Conservation, 118(4): 467-478, doi:10.1016/j.biocon.2003.09.022. 4.3

Aumand, A., Barthélemy, D., Caron, P. (2006), "Definitions, references and interpretations of the concept of multifunctionality in France", European Series on Multifunctionality, 10: 5-39. Related online version (cited on 23 May 2007):

http://www.inra.fr/sed/multifonction/EuSeriesMF.htm. 2

Ayres, R.U., Kneese, A.V. (1969), "Production, Consumption and Externalities", American Economic Review, 59(3): 282-297. 2.1

Bastian, O., Schreiber, K.-F. (1999), Analyse und ökologische Bewertung der Landschaft, Heidelberg (Spektrum). 2.2

Batie, S.S. (2001), "Public Programs and Conservation on Private Lands", "Private Lands, Public Benefits: A Policy Summit on Working Lands Conservation", NGA summit Washington, DC, March 16, 2001, conference paper. Related online version (cited on 23 May 2007): http://www.nga.org/Files/pdf/LANDSPUBPROG.pdf. 4.2

Belletti, G., Brunori, G., Marescotti, A., Rossi, A. (2003), "Multifunctionality and rural development: a multilevel approach", in Multifunctional Agriculture: A New Paradigm for European Agriculture and Rural Development, (Eds.) Van Huylenbroeck, G., Durand, G., Perspectives on Rural Policy and Planning, pp. 55-81, Aldershot; Burlington, VT (Ashgate). 3

Bennett, J., van Bueren, M., Whitten, S. (2004), "Estimating society's willingness to pay to maintain viable rural communities", Australian Journal of Agricultural and Resource Economics, 48(3): 487-512, doi:10.1111/j.1467-8489.2004.00254.x. 4.2 
Benton, T.G., Vickery, J.A., Wilson, J.D. (2003), "Farmland biodiversity: is habitat heterogeneity the key?", Trends in Ecology 6 Evolution, 18(4): 182-188, doi:10.1016/S0169-5347(03)00011-9. 4.3

Bertolini, P., Giovannetti, E. (2006), "Industrial districts and internationalization: the case of the agri-food industry in Modena, Italy", Entrepreneurship 6 Regional Development, 18(4): 279-304, doi:10.1080/08985620600613761. 6

Blandford, D. (1999), "Globalization and Northeast Agriculture: Implications of the Upcoming Round of World Trade Negotiations", Agricultural and Resource Economics Review, 28(2): 128136. 5.1

Blandford, D., Boisvert, R.N. (2002), "Multi-Functional Agriculture and Domestic/International Policy Choice", Estey Centre Journal of International Law and Trade Policy, 3(1): 106-118. URL (cited on 23 May 2007):

http://www.esteyjournal.com/. 5.1

Blandford, D., Boisvert, R.N. (2004), "Multifunctional agriculture - A view from the United States", 90th EAAE Seminar: Multifunctional agriculture, policies and markets, October 2004, Rennes, France, conference paper. 2.2

Bohman, M., Cooper, J., Mullarkey, D., Normile, M.A., Skully, D., Vogel, S., Young, E. (1999), "The Use and Abuse of Multifunctionality", Washington, DC (Economic research Service, USDA). URL (cited on 23 May 2007):

http://www.ers.usda.gov/Briefing/wto/genuraa.htm. 5.1

Brodt, S., Feenstra, G., Kozloff, R., Klonsky, K., Tourte, L. (2006), "Farmer-Community Connections and the Future of Ecological Agriculture in California", Agriculture and Human Values, 23(1): 75-88, doi:10.1007/s10460-004-5870-y. 4.3

Burrell, A. (2001), "Multifunctionality and agricultural trade liberalisation", Tijdschrift voor Sociaalwetenschappelijk onderzoek in de Landbouw, 16(2): 77-95. 5.1

Burrell, A. (2003), "Multifunctionality, non-trade concerns and the Millennium round", in La multifonctionnalité de l'activité agricole, et sa reconnaissance par les politiques publiques actes du colloque international de la Société française d'économie rurale, 21-22 mars 2002, (Eds.) Barthélemy, D., Delorme, H., Losch, B., Moreddu, C., Nieddu, M., Conference on Multifunctionality organised by the SFER (Société française d'économie rurale, 22 March, Paris, France, Paris (Cirad Editions). 5.1

Burton, R.J.F., Wilson, G.A. (2006), "Injecting social psychology theory into conceptualisations of agricultural agency: Towards a post-productivist farmer self-identity?", Journal of Rural Studies, 22(1): 95-115, doi:10.1016/j.jrurstud.2005.07.004. 5.1, 6

Buysse, J., Van Huylenbroeck, G., Lauwers, L. (2007), "Normative, positive and econometric mathematical programming as tools for incorporation of multifunctionality in agricultural policy modelling", Agriculture, Ecosystems 65 Environment, 120(1): 70-81, doi:10.1016/j.agee.2006.03.035. $2.1,3$

Cahill, C. (2001), "Multifunctionality: towards an analytical framework", Tijdschrift voor Sociaalwetenschappelijk onderzoek in de Landbouw, 16(2): 59-71. 1, 3

Casavant, K.L., Infanger, C.L., Bridges, D.E. (1999), Agricultural Economics and Management, Upper Saddle River, New Jersey (Prentice Hall). 2.1

Living Reviews in Landscape Research

http://www. livingreviews.org/lrlr-2007-3 
Casini, L., Ferrari, S., Lombardi, G., Rambonilaza, M., Sattler, C., Waarts, Y. (2004), "Research Report on the Analytic Multifunctionality Framework", Müncheberg (MEA-Scope). URL (cited on 23 May 2007):

http://www.mea-scope.org/. 2.2

Chang, K., Ying, Y.-h. (2005), "External benefits of preserving agricultural land: Taiwan's rice fields", Social Science Journal, 42(2): 285-293, doi:10.1016/j.soscij.2005.03.008. 4.1

Cheshire, P., Sheppard, S. (1995), "On the price of land and the value of amenities", Economica, 62: $247-267.4 .1$

de Groot, R.S., Wilson, M.A., Boumans, R.M.J. (2002), "A typology for the classification, description and valuation of ecosystem functions, goods and services", Ecological Economics, 41 (3): 393-408, doi:10.1016/S0921-8009(02)00089-7. 2.2

de Lauwere, C., Verstegen, J., Buurma, J., Poot, E., Roelofs, P., van der Schans, J.W., Vrolijk, M., Zaalmink, W. (2006), "Ondernemers en de actoren in hun omgeving in beweging. Zoektocht naar rode draden in agrarische transitieprocessen", Den Haag (LEI). Related online version (cited on 23 May 2007):

http://www.lei . wur.nl/UK/publications+en+products/LEI+publications/default.htm? id $=690.5 .2$

de Roest, K., Menghi, A. (2000), "Reconsidering 'Traditional' Food: The Case of Parmigiano Reggiano Cheese", Sociologia Ruralis, 40(4): 439-451, doi:10.1111/1467-9523.00159. 5.2

Delgado, M., Ramos, E., Gallardo, R., Ramos, F. (2003), "Multifunctionality and rural development: a necessary convergence", in Multifunctional Agriculture: A New Paradigm for European Agriculture and Rural Development, (Eds.) Van Huylenbroeck, G., Durand, G., pp. 19-36, Aldershot; Burlington, VT (Ashgate). 1

Denys, C., Tscharntke, T. (2002), "Plant-insect communities and predator-prey ratios in field margin strips, adjacent crop fields, and fallows", Oecologia, 130(2): 315-324, doi: 10.1007/s004420100796. 4.3

Di Iacovo, F. (2003), "New trends in the relationship between farmers and local communities in Tuscany", in Multifunctional Agriculture: A New Paradigm for European Agriculture and Rural Development, (Eds.) Van Huylenbroeck, G., Durand, G., pp. 101-128, Aldershot; Burlington, VT (Ashgate). 4.2

Dobbs, T.L., Pretty, J.N. (2001), "The United Kingdom's Experience with Agri-Environmental Stewardship Schemes: Lessons and Issues for the United States and Europe", Brookings; Colchester (South Dakota State University; University of Essex). Related online version (cited on 23 May 2007):

http://agecon.lib.umn.edu/cgi-bin/detailview.pl?paperid=2436. 2, 5.1

Dobbs, T.L., Pretty, J.N. (2004), "Agri-Environmental Stewardship Schemes and 'Multifunctionality"', Review of Agricultural Economics, 26(2): 220-237, doi:10.1111/j.1467-9353.2004.00172.x. 1

Doll, J.P., Orazem, F. (1978), Production Economics, Theory with Applications, Columbus (Grid Inc.). 2.1

Donald, P.F., Evans, A.D. (2006), "Habitat connectivity and matrix restoration: the wider implications of agri-environment schemes", Journal of Applied Ecology, 43(2): 209-218, doi: 10.1111/j.1365-2664.2006.01146.x. 4.3 
Doornbos, G., Pastoor, B. (2001), "Multifunctionaliteit in landbouwbeleid", Tijdschrift voor Sociaalwetenschappelijk onderzoek in de Landbouw, 16(2): 110-113. 2.1

Evans, N., Gaskell, P., Winter, M. (2003), "Re-assessing agrarian policy and practice in local environmental management: the case of beef cattle", Land Use Policy, 20(3): 231-242, doi: 10.1016/S0264-8377(03)00026-7. 4.3

Fahlbeck, E. (2004a), "Private provision of agricultural public goods in Sweden", 90th EAAE Seminar "Multifunctional agriculture, policies and markets: understanding the critical linkage", Rennes, October 28-29, conference paper. Related online version (cited on 23 May 2007): http://merlin.lusignan.inra.fr:8080/eaae/website/ContributedPapers. 2

Fahlbeck, E. (2004b), "Borderlines for a Common Agricultural Policy of Multifunctional Agriculture", in Role of Institutions in Rural Policies and Agricultural Markets, (Eds.) Van Huylenbroeck, G., Lauwers, L., Verbeke, W., pp. 323-334, Amsterdam (Elsevier). 2

Färe, R., Grosskopf, S., Lovell, C.A.K., Yaisawarng, S. (1993), "Derivation of Shadow Prices for Undesirable Outputs: A Distance Function Approach.", Review of Economics and Statistics, 75 (2): $374-380.2 .1$

Ferrari, S. (2004), "Multifunctionality of agriculture and joint production", 90th EAAE Seminar: Multifunctional agriculture, policies and markets, October 2004, Rennes, France, conference paper. 3

Fleischer, A., Tchetchik, A. (2005), "Does rural tourism benefit from agriculture?", Tourism Management, 26(4): 493-501, doi:10.1016/j.tourman.2003.10.003. 4.1

Fleischer, A., Tsur, Y. (2000), "Measuring the recreational value of agricultural landscape", European Review of Agricultural Economics, 27(3): 385-398, doi:10.1093/erae/27.3.385. 4.1

Freshwater, D., Jia, H. (2004), "Improving our understanding of joint production as the basis for multifunctionality", 90th EAAE Seminar: Multifunctional agriculture, policies and markets, October 2004, Rennes, France, conference paper. 2.1, 2.1

Fuller, R.J., Hinsley, S.A., Swetnam, R.D. (2004), "The relevance of non-farmland habitats, uncropped areas and habitat diversity to the conservation of farmland birds", Ibis, 146(s2): 22-31, doi:10.1111/j.1474-919X.2004.00357.x. 4.3

Gallardo, R., Ramos, F., Ramos, E., Delgado, M. (2003), "New opportunities for non-competitive agriculture", in Multifunctional Agriculture: A New Paradigm for European Agriculture and Rural Development, (Eds.) Van Huylenbroeck, G., Durand, G., pp. 169-188, Aldershot; Burlington, VT (Ashgate). 5.1

Garrod, G.D., Whitby, M.C. (2005), Strategic Countryside Management, Amsterdam (Elsevier). 4.1

Garrod, G.D., Willis, K.G. (1992), "Valuing goods' characteristics: An application of the hedonic price method to environmental attributes", Journal of Environmental Management, 34(1): 5976, doi:10.1016/S0301-4797(05)80110-0. 4.1

Geoghegan, J. (2002), "The value of open spaces in residential land use", Land Use Policy, 19(1): 91-98, doi:10.1016/S0264-8377(01)00040-0. 4.1

Gibson, A. (2005), "Managing grassland for production, the environment and the landscape. Challenges at the farm and the landscape level", Livestock Production Science, 96(1): 11-31, doi: 10.1016/j.livprodsci.2005.05.009. 4.3

Living Reviews in Landscape Research

http://www. livingreviews.org/lrlr-2007-3 
Gilg, A.W., Battershill, M. (1999), "The Role of Household Factors in Direct Selling of Farm Produce in France", Tijdschrift voor economische en sociale geografie, 90(3): 312-319, doi: 10.1111/1467-9663.00072. 4, 5.1

Goodman, D. (1999), "Agro-Food Studies in the 'Age of Ecology': Nature, Corporeality, BioPolitics", Sociologia Ruralis, 39(1): 17-38, doi:10.1111/1467-9523.00091. 6

Hall, C., McVittie, A., Moran, D. (2004), "What does the public want from agriculture and the countryside? A review of evidence and methods", Journal of Rural Studies, 20(2): 211-225, doi:10.1016/j.jrurstud.2003.08.004. 4.2

Hall, D., Rosillo-Calle, F. (1999), "The Multifunctional Character of Agriculture and Land: the energy function (Background Paper 2: Bioenergy)", in Background Papers: FAO/Netherlands Conference on the Multifunctional Character of Agriculture and Land, (Ed.) Trenchard, R., Rome (FAO). URL (cited on 23 May 2007):

http://www.fao.org/mfcal/pdf/bp_2_bio.pdf. Maastricht, 12-17 September 1999. 4

Hanley, N., Shogren, J.F., White, B. (2006), Environmental economics in theory and practice, Houndmills Basingstoke; New York (Palgrave Macmillan). 5.2

Harwood, R.R. (2003), "Sustainable Agriculture on a Populous Industrialized Landscape: Building Ecosystems' Vitality and Productivity", in Food Security and Environmental Quality in the Developing World, (Eds.) Lal, R., Hansen, D., Uphoff, N., Slack, S., Boca Raton, FL (Lewis Publishers/CRC Press). 2

Havlik, P., Veysset, P., Boisson, J.-M., Lherm, M., Jacquet, F. (2005), "Joint production under uncertainty and multifunctionality of agriculture: policy considerations and applied analysis", European Review of Agricultural Economics, 32(4): 489-515, doi:10.1093/erae/jbi027. 2.1, 2, 2.1

Hediger, W. (2004), "On the economics of multifunctionality and sustainability of agricultural systems", 90th EAAE Seminar: Multifunctional agriculture, policies and markets, October 2004, Rennes, France, conference paper. 2, 2.2

Helming, K., Wiggering, H. (2003), Sustainable development of multifunctional landscapes, Berlin (Springer). 1

Hinsley, S.A., Bellamy, P.E. (2000), "The influence of hedge structure, management and landscape context on the value of hedgerows to birds: A review", Journal of Environmental Management, 60(1): 33-49, doi:10.1006/jema.2000.0360. 4.3

Holmes, J. (2002), "Diversity and change in Australia's rangelands: a post-productivist transition with a difference?", Transactions of the Institute of British Geographers, 27(3): 362-384. 5.1

Howarth, R.B., Wilson, M.A. (2006), "A Theoretical Approach to Deliberative Valuation: Aggregation by Mutual Consent", Land Economics, 82(1): 1-16. 4

Hyytiä, N., Kola, J. (2006), "Finnish Citizens' Attitudes towards Multifunctional Agriculture", International Food and Agribusiness Management Review, 9(3): 1-22. 4.2

Irwin, E.G. (2002), "The Effects of Open Space on Residential Property Values", Land Economics, 78(4): 465-480. 4.1

Irwin, E.G., Bockstael, N.E. (2001), "The Problem of Identifying Land Use Spillovers: Measuring the Effects of Open Space on Residential Property Values", American Journal of Agricultural Economics, 83(3): 698-704, doi:10.1111/0002-9092.00193. 4.1 
Jacobs, M. (1997), "Environmental valuation, deliberative democracy and public decision-making", in Valuing nature: Economics, Ethics and Environment, (Ed.) Foster, J., pp. 211-231, London (Routledge). 4

Jongeneel, R.A., Slangen, L.H.G. (2004), "Multifunctionality in agriculture and the contestable public domain: theory and evidence about on-farm and off-farm activities in the Netherlands", in Sustaining Agriculture and the Rural Environment: Governance, Policy and Multifunctionality, (Ed.) Brouwer, F., Advances in Ecological Economics, pp. 183-203, Cheltenham (Edward Elgar). 2

Jongeneel, R.A., Polman, N.B.P., Slangen, L.H.G. (2005), "Why are farmers going multifunctional?", XIth International Congress of the EAAE 'The Future of Rural Europe in the Global Agri-Food System', 24-27 August 2005, Copenhagen, Denmark, conference paper. Related online version (cited on 23 May 2007):

http://de.scientificcommons.org/1164613. 4, 5.1

Kahneman, D., Knetsch, J.L. (1992), "Valuing Public Goods: The Purchase of Moral Satisfaction", Journal of Environmental Economics and Management, 22(1): 57-70, doi:10.1016/00950696(92)90019-S. 4

Kallas, Z., Gómez-Limón, J.A., Arriaza, M. (2007), "Are citizens willing to pay for agricultural multifunctionality?", Agricultural Economics, 36(3): 405-419, doi:10.1111/j.15740862.2007.00216.x. 4.2

Kirwan, J., Vorley, B., Foster, C., Fearne, A. (2007), "Re-localising national agrifood procurement and distribution systems: the development of locally-embedded networks of provision", in Sustaining food supply chains: grounded perspectives on the dynamics and impact of new modes of food provision, (Eds.) Wiskerke, J.S.C., Van Huylenbroeck, G., Kirwan, J., Aldershot; Burlington, VT (Ashgate). Upcoming. 5.2

Kleijn, D., Sutherland, W.J. (2003), "How effective are European agri-environment schemes in conserving and promoting biodiversity?", Journal of Applied Ecology, 40(6): 947-969, doi: 10.1111/j.1365-2664.2003.00868.x. 4.3

Knickel, K., Renting, H. (2000), "Methodological and Conceptual Issues in the Study of Multifunctionality and Rural Development", Sociologia Ruralis, 40(4): 512-528, doi:10.1111/14679523.00164. 5.1

Kumar, M., Kumar, P. (2004), IEG Discussion Papers, 87/2004, Delhi (Institute of Economic Growth, Univeristy of Delhi Enclave). URL (cited on 23 May 2007):

http://iegindia.org/dispap.htm. Presented at 8th Scientific Conference of the ISEE, Montreal, July 11-14, 2004. 4

Loureiro, M.L., Jervell, A.M. (2005), "Farmers' participation decisions regarding agro-tourism activities in Norway", Tourism Economics, 11(3): 453-469. 4, 5.1

MacDonald, D., Crabtree, J.R., Wiesinger, G., Dax, T., Stamou, N., Fleury, P., Gutierrez Lazpita, J., Gibon, A. (2000), "Agricultural abandonment in mountain areas of Europe: Environmental consequences and policy response", Journal of Environmental Management, 59(1): 47-69, doi: 10.1006/jema.1999.0335. 4.3

Maier, L., Shobayashi, M. (2001), "Multifunctionality: Towards an Analytical Framework", Paris (OECD Publications Service). 1, 2, 2.1, 2.2, 3

Living Reviews in Landscape Research

http://www. livingreviews.org/lrlr-2007-3 
Mander, Ü., Wiggering, H., Helmig, K. (Eds.) (2007), Multifunctional Land Use: Meeting Future Demands for Landscape Goods and Services, Berlin; New York (Springer). 2

Marsden, T.K., Banks, J., Bristow, G. (2002), "The social management of rural nature: understanding agrarian-based rural development", Environment and Planning A, 34(5): 809-825, doi:10.1068/a3427. 5.1, 6

Marshall, E.J.P., West, T.M., Kleijn, D. (2006), "Impacts of an agri-environment field margin prescription on the flora and fauna of arable farmland in different landscapes", Agriculture, Ecosystems \&3 Environment, 113(1-4): 36-44, doi:10.1016/j.agee.2005.08.036. 4.3

McNally, S. (2001), "Farm diversification in England and Wales - what can we learn from the farm business survey?", Journal of Rural Studies, 17(2): 247-257, doi:10.1016/S0743-0167(00)000504. $4,5.1$

Ménard, C. (2003), "L'approche néo-institutionnelle: des concepts, une méthode, des résultats", Cahiers d'économie politique, 44: 103-118. Related online version (cited on 23 May 2007): http://atom.univ-paris1.fr/documents/M_nard_2003f_Approche_Neo_institutionnelle . pdf. 6

Ménard, C. (2004), "The Economics of Hybrid Organizations", Journal of Institutional and Theoretical Economics, 160(3): 1-32. 6

Merlo, M. (2001), "Marketing of environmental goods and services linked to farming and forestry: an opportunity for rural areas under urban pressure", in Open space functions under urban pressure (Open-ruimtefuncties onder verstedelijkingsdruk), Proceedings of the Symposium, September 19-21, 2001, Ghent, Brussels (Administratie Land- en Tuinbouw). CD-ROM. 5.2

Milestad, R., Hadatsch, S. (2003), "Growing out of the niche - can organic agriculture keep its promises? A study of two Austrian cases", American Journal of Alternative Agriculture, 18(3): 155-163, doi:10.1079/AJAA200347. 5.2

Mitsh, W.J., Gosselinck, J.G. (2000), "The value of wetlands: importance of scale and landscape setting", Ecological Economics, 35(1): 25-33, doi:10.1016/S0921-8009(00)00165-8. 4.3

Mollard, A. (2003), "Multifonctionnalité de l'agriculture et territoires: des concepts aux politiques publiques", Cahiers d'économie et sociologie rurales, 66: 27-54. Related online version (cited on 23 May 2007):

http://www.inra.fr/esr/publications/cahiers/cesr66f.php. 2.2

Moon, W., Kuethe, T.H., Kraft, S.E., Esseks, J.D. (2005), "Public Preferences for Multifunctional Benefits of Agriculture: National Survey of Registered Voters", American Agricultural Economics Association Annual Meeting, July 24-27, Providence, Rhode Island, conference paper. Related online version (cited on 23 May 2007):

http://agecon.lib.umn.edu/cgi-bin/detailview.pl?paperid=16514. 4.2

Moyer, W., Josling, T. (2002), Agricultural Policy Reform: Politics and Process in the EU and US in the 1990s, Global Environmental Governance, Aldershot; Burlington, VT (Ashgate). 2, 5.1, 1

Murdoch, J. (2000), "Networks - a new paradigm of rural development?", Journal of Rural Studies, 16(4): 407-419, doi:10.1016/S0743-0167(00)00022-X. 6 
Nestlé (2006), "Nestlé Supports the Sustainable Use of Water and Presents its 5 Commitments on Water", Issy-les-Moulineaux, France (Nestlé Waters Group). Related online version (cited on 23 May 2007):

http://press.nestle-waters.com/en/Menu/PressKit/. Press kit on occasion of World Water Expo/Water Fair at the 4th World Water Forum, 16-21 March 2006, Mexico. 5.2

Oerlemans, N., Hees, E. (2006), "Building a strong brand", in Nourishing Networks - Fourteen lessons about creating sustainable food supply chains, (Eds.) Roep, D., Wiskerke, H., pp. 91102, Doetinchem, The Netherlands (Rural Sociology Group of Wageningen University and Reed Business Information). 5.2

Orden, D., Paarlberg, R., Roe, T. (1999), Policy Reform in American Agriculture, Chicago (University of Chicago Press). 5.1

Overbeek, M.M.M., Terluin, I.J. (2006), "Rural Areas Under Urban Pressure: Case studies of rural-urban relationships across Europe", 7.06.01, The Hague (LEI Wageningen UR). Related online version (cited on 23 May 2007):

http://www.lei.wur.nl/UK/publications+en+products/LEI+publications/default.htm? id $=674.5 .2$

Palmquist, R.B., Roka, F.M., Vukina, T. (1997), "Hog operations, environmental effects and resident property values", Land Economics, 73(1): 114-124. 4.1

Penker, M. (2006), "Mapping and measuring the ecological embeddedness of food supply chains", Geoforum, 37(3): 368-379, doi:10.1016/j.geoforum.2005.09.001. 5.2

Poe, G.L. (1999), “'Maximizing the Environmental Benefits per Dollar Expended': An Economic Interpretation and Review of Agricultural Environmental Benefits and Costs", Society 8 Natural Resources, 12(6): 571-598, doi:10.1080/089419299279452. 4.2

Polman, N.B.P. (2002), Institutional Economics Analysis of Contractual Arrangements; Managing Wildlife and Landscape on Dutch Farms, Master's Thesis, Wageningen University, Wageningen. 5.2

Potter, C. (2006), "Competing narratives for the future of European agriculture: the agrienvironmental consequences of neoliberalization in the context of the Doha Round", Geographical Journal, 172(3): 190-196, doi:10.1111/j.1475-4959.2006.00210.x. 5.1, 5.1

Potter, C., Burney, J. (2002), "Agricultural multifunctionality in the WTO-legitimate non-trade concern or disguised protectionism?", Journal of Rural Studies, 18(1): 35-47, doi:10.1016/S07430167(01)00031-6. 5.1

Potter, C., Tilzey, M. (2005), "Agricultural policy discourses in the European post-Fordist transition: neoliberalism, neomercantilism and multifunctionality", Progress in Human Geography, 29(5): 581-600, doi:10.1191/0309132505ph569oa. 1, 5.1, 6

Randall, A. (2002), "Valuing the outputs of multifunctional agriculture", European Review of Agricultural Economics, 29(3): 289-307, doi:10.1093/eurrag/29.3.289. 2.2, 4

Ready, R., Abdalla, C.W. (2005), "The Amenity and Disamenity Impacts of Agriculture: Estimates From a Hedonic Pricing Model", American Journal of Agricultural Economics, 87(2): 314-326, doi:10.1111/j.1467-8276.2005.00724.x. 4.1

Renting, H., Marsden, T.K., Banks, J. (2003), "Understanding alternative food networks: exploring the role of short food supply chains in rural development", Environment and Planning A, 35(3): 393-411, doi:10.1068/a3510. 2

Living Reviews in Landscape Research

http://www. livingreviews.org/lrlr-2007-3 
Roberts, L., Hall, D. (2001), Rural Tourism and Recreation: Principles to Practice, Wallingford (CABI Publishing). 4.1

Roe, B., Irwin, E.G., Morrow-Jones, H.A. (2004), "The Effects of Farmland, Farmland Preservation, and Other Neighborhood Amenities on Housing Values and Residential Growth", Land Economics, 80(1): 55-75. 4.1

Romstad, E. (2004), "Multifunctionality - focus and resource allocation", 90th EAAE Seminar: Multifunctional agriculture, policies and markets, October 2004, Rennes, France, conference paper. 2.1

Romstad, E., Vatn, A., Rørstadt, P.K., Søyland, V. (2000), IØS Meldinger, 21/2000, Ås (Agricultural University of Norway, Department of Economics and Social Sciences). URL (cited on 23 May 2007):

http://www.nlh.no/ios/Publikasjoner/melding/m-21.html. 2.1

Schmitzberger, I., Wrbka, T., Steurer, B., Aschenbrenner, G., Peterseil, J., Zechmeister, H.G. (2005), "How farming styles influence biodiversity maintenance in Austrian agricultural landscapes", Agriculture, Ecosystems \&3 Environment, 108(3): 274-290, doi: 10.1016/j.agee.2005.02.009. 5.1

Scrase, J.I., Sheate, W.R. (2005), "Re-framing Flood Control in England and Wales", Environmental Values, 14(1): 113-137. 4.3

Sharpley, R., Vass, A. (2006), "Tourism, farming and diversification: An attitudinal study", Tourism Management, 27(5): 1040-1052, doi:10.1016/j.tourman.2005.10.025. 4.2

Sonnino, R. (2007), "Embeddedness in action: Saffron and the making of the local in southern Tuscany", Agriculture and Human Values, 24(1): 61-74, doi:10.1007/s10460-006-9036-y. 6

Spash, C.L. (2000), "Ecosystems, contingent valuation and ethics: the case of wetland re-creation", Ecological Economics, 34(2): 195-215, doi:10.1016/S0921-8009(00)00158-0. 4

Spash, C.L. (2002), "Informing and forming preferences in environmental valuation: Coral reef biodiversity", Journal of Economic Psychology, 23(5): 665-687, doi:10.1016/S0167-4870(02)00123X. 4

Stedula (2004), "Op grond van morgen: Visie op landbouw in Vlaanderen, anno 2030", Gontrode (Flemish Policy Research Centre for Sustainable Agriculture (Stedula)). URL (cited on 23 May 2007):

http://www.kuleuven.ac.be/stedula/nl/dula/inschrijvingworkshop.php. 5.2

Swetnam, R.D., Mountford, J.O., Manchester, S.J., Broughton, R.K. (2004), "Agri-environmental schemes: their role in reversing floral decline in the Brue floodplain, Somerset, UK", Journal of Environmental Management, 71(1): 79-93, doi:10.1016/j.jenvman.2004.01.006. 4.3

Thompson, K. (2004), "Multifunctional agriculture: a new paradigm for European agriculture and rural development (Book review)", Journal of Agricultural Economics, 55(3): 653-655. 6

Tyrväinen, L., Miettinen, A. (2000), "Property Prices and Urban Forest Amenities", Journal of Environmental Economics and Management, 39(2): 205-223, doi:10.1006/jeem.1999.1097. 4.1

van der Ploeg, J.D., Roep, D. (2003), "Multifunctionality and rural development: the actual situation in Europe", in Multifunctional Agriculture: A New Paradigm for European Agriculture and Rural Development, (Eds.) Van Huylenbroeck, G., Durand, G., pp. 37-54, Aldershot; Burlington, VT (Ashgate). 2, 3, 4, 5.1 
Van Huylenbroeck, G. (2005), "Market and rural policy institutions to stimulate multifunctionality in food and fibre production", International Seminar, Padova, conference paper. 5.2, 8

Van Huylenbroeck, G., Durand, G. (Eds.) (2003), Multifunctional Agriculture: A New Paradigm for European Agriculture and Rural Development, Aldershot; Burlington, VT (Ashgate). 5.1

Van Huylenbroeck, G., Slangen, L.H.G. (2003), "Nieuwe institutionele arrangementen in het landelijk gebied", Tijdschrift voor Sociaalwetenschappelijk onderzoek in de Landbouw, 18(2): 107121. 5.2

Van Huylenbroeck, G., Vanslembrouck, I. (2001), "Organising demand for and supply of multifunctionality at farm level", Tijdschrift voor Sociaalwetenschappelijk onderzoek in de Landbouw, 16(2): 96-107. 3,3

Van Huylenbroeck, G., Van Hecke, E., Meert, H., Vandermeulen, V., Verspecht, A., Vernimmen, T., Boulanger, A., Luyten, S. (2005), "Overlevingsstrategieën voor een Multifunctionele Landbouw in Verstedelijkte Gebieden (Development strategies for a multifunctional agriculture in periurban areas)", Brussels (Belgian Federal Science Policy Office). Related online version (cited on 23 May 2007):

http://www.belspo.be/belspo/home/publ/rappCPagr_en.stm. 4.2

Van Huylenbroeck, G., Vanslembrouck, I., Calus, M., Van de Velde, L. (2006), "Synergies between Farming and Rural Tourism: Evidence from Flanders", EuroChoices, 5(1): 14-21, doi: 10.1111/j.1746-692X.2006.00021.x. 4.1

Vandermeulen, V., Van Huylenbroeck, G. (2006a), "Decentralized rural development policies: does it make sense: the example of diversification in Flanders", 26th Conference of the IAAE "Contributions of Agricultural Economics to Critical Policy Issues", 12-18 August 2006, Queensland, Australia, conference paper. 4

Vandermeulen, V., Van Huylenbroeck, G. (2006b), "Flanders Vegetable Valley: an exemplary case of the influence of competitive networks on the developments in agriculture", in Causes and Impacts of Agricultural Structures, (Ed.) Mann, S., pp. 201-218, Hauppauge, NY (Nova Publishers). 5.2

Vandermeulen, V., Verspecht, A., Van Huylenbroeck, G., Meert, H., Boulanger, A., Van Hecke, E. (2006), "The importance of the institutional environment on multifunctional farming systems in the peri-urban area of Brussels", Land Use Policy, 23(4): 486-501, doi: 10.1016/j.landusepol.2005.06.002. 5.2

Vanslembrouck, I., Van Huylenbroeck, G. (2005), Landscape Amenities: Economic Assessment of Agricultural Landscapes, vol. 2 of Landscape Series, Dordrecht (Springer Netherlands). 2, 3, 4

Vanslembrouck, I., Van Huylenbroeck, G., Verbeke, W. (2002), "Determinants of the Willingness of Belgian Farmers to Participate in Agri-environmental Measures", Journal of Agricultural Economics, 53(3): 489-511. 4, 5.1

Vanslembrouck, I., Van Huylenbroeck, G., Van Meensel, J. (2005), "Impact of Agriculture on Rural Tourism: A Hedonic Pricing Approach", Journal of Agricultural Economics, 56(1): 17-30. 4.1

Varian, H.R. (2002), Intermediate Microeconomics: A Modern Approach, London (W.W. Norton \& Co.), 6th edn. 2.1

Living Reviews in Landscape Research

http://www. livingreviews.org/lrlr-2007-3 
Vatn, A. (2000), IØS Diskusjonsnotater / Discussion Papers, D-18/2000, Ås (Agricultural University of Norway, Department of Economics and Social Sciences). Related online version (cited on 23 May 2007):

http://www.nlh.no/ios/Publikasjoner/d2000/d2000-18.html. Seminar: Role of Multifunctionality in Agricultural Policy Reform, January 26 - February 3, 2000, Tokyo, Japan. 2.1

Vatn, A. (2002), "Multifunctional agriculture: some consequences for international trade regimes", European Review of Agricultural Economics, 29(3): 309-327. 2.1, 2.1, 2.2

Walford, N. (2003), "Productivism is allegedly dead, long live productivism. Evidence of continued productivist attitudes and decision-making in South-East England", Journal of Rural Studies, 19(4): 491-502, doi:10.1016/S0743-0167(03)00030-5. 5.1

West, T.O., Marland, G. (2003), "Net carbon flux from agriculture: Carbon emissions, carbon sequestration, crop yield, and land-use change", Biogeochemistry, 63(1): 73-83, doi: 10.1023/A:1023394024790. 4.3

Wiggering, H., Dalchow, C., Glemnitz, M., Helming, K., Müller, K., Schultz, A., Stachow, U., Zander, P. (2006), "Indicators for multifunctional land use - Linking socioeconomic requirements with landscape potentials", Ecological Indicators, 6(1): 238-249, doi: 10.1016/j.ecolind.2005.08.014. 5.2, 2

Wilson, G.A. (2001), "From productivism to post-productivism ... and back again? Exploring the (un)changed natural and mental landscapes of European agriculture", Transactions of the Institute of British Geographers, 26(1): 77-102, doi:10.1111/1475-5661.00007. 2, 5.1

Wilson, G.A. (2004), "The Australian Landcare movement: towards 'post-productivist' rural governance?", Journal of Rural Studies, 20(4): 461-484, doi:10.1016/j.jrurstud.2004.03.002. 2, 5.1, 6

Wossink, G.A.A., Lansink, A.G.J.M.O., Struik, P.C. (2001), "Non-separability and heterogeneity in integrated agronomic-economic analysis of nonpoint-source pollution", Ecological Economics, 38(3): 345-357, doi:10.1016/S0921-8009(01)00170-7. 2.1

Zhang, Y.Q., Li, Y.Q. (2005), "Valuing or pricing natural and environmental resources?", Environmental Science \& Policy, 8(2): 179-186, doi:10.1016/j.envsci.2004.09.005. 4 